を用いて，視運動刺激を被検動物に加えた。この装置 は天井から吊り下げた直径 $2.0 \mathrm{~m}$, 高さ $1.9 \mathrm{~m}$ の中空性 大円筒で丁度，吊り鐘状を呈している，大円筒の内面 には巾 $4.0 \mathrm{~cm}$ の黒い綐線を15本，等間隔に附してある。 大円筒は電気的に右拈よび左に加速回転されるが，円 筒の回転による黒い縦線の右爻は左への移動は被検動 物にとつて視運動刺激となる。この際これまでの経験 から考えると，円筒回転が速くなり，黒線が速く移動 すると視運動刺激は強烈となるといい得る.

\section{（2）実験動物と動物の固定方法 ;}

黒眼, 成熟ウサギ (体重 $2.5 \mathrm{~kg} \sim 3.0 \mathrm{~kg}$ )，8 羽を用い た. 実験に先立つて, 被検動物は鼓膜正常で，かつ回 転検査で迷路反射に異常のないことを確めている．被 検動物の軀幹, 四肢は図(1)に示したような固定器で 固定されているが，頭部，頸部は空中に自由にされて いる，回定された動物は，(1)で述べた大円筒中央に設 けられた台上におかれ，円筒回転による視運動刺激を うけることになる。

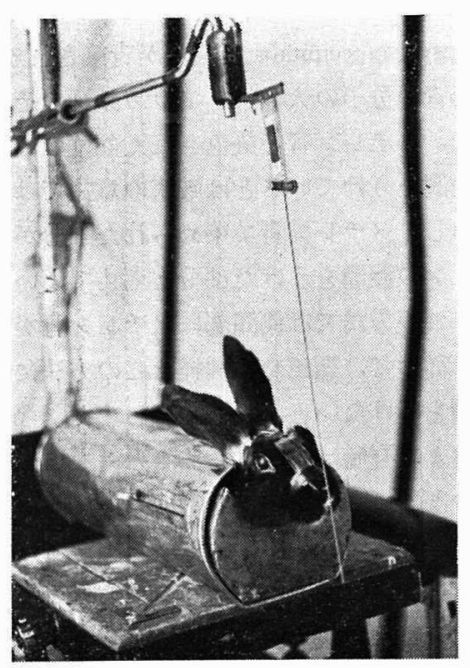

Fig. 1

（3）視性反射測定と視運動剌激反覆負荷 (視性訓練)に用いた視運動剌激 ;

この実験で用いた視運動刺激は目的によつて，次ぎ の2つに分けられている。すなわち，1つは動物が以 下述べ視運動刺激反覆(視性訓練)を通じて視性反射 が変化する際，その状況を観察するため，すなわち， 視性訓練効果を測定するために用いられる視運動刺激 である. 他の 1 つは，この動物に対して行なわれる視 性訓練に用いられる視運動刺激である。視性訓練勃果
測定に用いられる視運動刺激は上述の大円筒を角加速 度 $1 \% / \mathrm{sec}^{2}$ で初速 $0^{\circ}$ から最高速 $160^{\circ} / \mathrm{sec}$ まで回転して 得られるものである。この場合は大円筒を右または左 に，それぞれ 5 分間の間隔を置いて回転し，動物の視 性反射を測定した．視性訓練に用いた視運動刺激は， 同じ大円筒を，おなじ角加速度で初速 0 ○から最高速 $160 \%$ sec まで回転し与えるものであるが，右および左 への回転は各々 1 回あてとした，そして各回転は 5 分 間の間隔を置いて行なわれた、これがこの動物に与え られる 1 日の視運動刺激量，すなわち，1日の視性訓 練量である、筆者はこの刺激量を被検動物に隔日に計 15回連続して与え，これをもつて視性訓練の 1 コース とした・したがつて動物は30日間にわたつてこの視運 動刺激をうけることになる、隔日に視運動刺激を加え て訓練した理由は，後で述へるようにこの同じ動物は 頸筋をプロカインで麻酔された条件下で視性訓練をう けるためである，連日プロカインを注射する場合，プ ロカインにより，動物が全身状態を低下し，そのため に視性訓練による視運動刺激適応性の獲得吕不良とな るのではないかという㲘念をできるだけさけるため に，上术のような操作で訓練した。なお，1日おきに 15回の頸部へのプロカイン注射が，ウサギの視性反射 にどの上うに影響するかについては後述したい．

\section{（4）視性反射の測定とその記録方法；}

視性反射梳視性眼反射(特に視性眼振) 飞視性脊䯣反 射(特に視性頍桭)を同時に観察することにした。これ はこれまでの我々の教室で行なわれた実験成績より， この際の眼球運動と頭部運動は被検動物の平衡機能維 持に当つて密に連関して活動していることが判明して いること，並びに動物の頭部運動の記録に関しては， 教室の寺山の実験があり，充分にその成績を参照でき るからである。

さて，頭部運動を観察するためには，检，北原，お よび寺山等によつて報告されたストレンゲージ計器を 使用した (Hinoki and Kitahara ${ }^{16)}$, 寺山 $\left.{ }^{37)}\right)$. また, 眼 球運動の記録には眼振電計を應用した，視性反射の観 察は，視運動刺激反覆負荷前，すなわち，視性訓練 前，および訓練15回目に測定した．なおここで申し 添えておきたいことは，被検動物に何等操作を加えな いで訓練を行なつた場合でも，また後述するようにプ ロカインを頸部に注射して訓練を行なう場合でも，視 性反射が測定される場合には頸部には何等操作は行な われていない，また，何れの訓練の場合でも15回目の 視性訓練が完了し24時間を経て訓練効果が測定されて 
いる．従つてプロカインで頸筋を麻酔して行なう視性 訓練の場合についていうなら，視性反射測定時にはプ ロカインの視性反射におよほす影響は，後述するよう な予備実験の成績より考えて除外してょいと考えてい る.

\section{（5）被検動物の頸部深部受容器の機能封鎖方法;}

筆者の実験目的から考えると，視性訓練を行なう際 には頸部深部受容器の機能が一過性に封鎖され，視性 訓練効果が測定される際には, この器官の機能に何等 障害のないことが望ましい. 従来, 頸部深部受容器の 機能の脱落が眼反射にどのような影響を与えるかを明 らかにするためには，多くの場合，頸部の脊髄知覚神 経(後根)が切断されている. しかし，実際に，この操 作を行なつてみると頸筋を頸椎より剝離しなければな らず，また，その際の出血は決して少量でない。しか も，この操作によりすでに後根が切断されているので この動物の正常時の成績とは比較にならない，特に筆 者の実験のように同一動物を用い頸筋の深部受容器が 健在の場合と，この機能が脱落または低下している場 合の訓練による視運動刺激適応性獲得を比較する際に は，従来のような方法で被検動物に強い障害を加える ことは極力さけなければならない，また，術者の技術 の進歩で後根を巧みに切断し得たとしても, 後根中に は, 関節，筋，および皮膚の受容器よりの求心性線維 を含んでいる筈である.したがつて何れの器官の受容 器が視性訓練効果獲得において, 視器により有効に協 力するかを，更に細分して考える訳には行かない。こ のような理由で筆者は, 桧, 寺山が報告した方法によ つてプロカイン溶液を被検動物の頸筋に注射し，この 部の筋肉に分布する $\gamma$ 線維の機能を低下，または脱落 させ，ひいてはその部の深部受容器からの求心性イン パルスを低下，または一過性に脱落させる方法を採用 した. (Hinoki and Terayama ${ }^{15)}$ ).

さて，骨格筋の緊張を司る器官は筋紡錘である 最 近の研究ではこの器官の活動性を支配するのは, $\gamma$ 線 維と呼ばれる細い遠心性線維であることが知られてい る. Matthewsのネコの M. soleus を対象とした実験で は， $\gamma$ 線維はプロカインに対する抵抗力が弱く, 運動 線維 ( $\alpha$ 線維) および知覚線維 (後根線維) の機能が重 篤に障害を受けぬ時期に，既にプロカインによりその 機能を著しく低下，または脱落することが判つている (Matthews and Rushworth ${ }^{28}$ ). )。た, Walshe, 島津の 報告によると，骨格筋に分布する $\gamma$ 線維の機能をプロ カインで閉鎖するためには，その筋肉内に直接プロカ
インを注射するとよいといわれている (Walshe ${ }^{40)}$, 島 津 $\left.{ }^{32)}\right)$. したがつて，プロカインを目的とする骨格筋 内に注射し，注射後一定の時期を選んで実験すると， 上述した目的に合致した条件下に実験を進めることが 可能となる.

筆者は，ウサギの浅層項筋群，おび哚層項筋群に 1 \%プロカイン溶液を注射して実験を行つた. 浅層項筋 群へのプロカイン注射は第三頸椎棘突起の高さで，そ の両側に注射針を浅く刺入し，片側 $1.5 \mathrm{cc}$ 宛, 両側, 計 3.0ccを注射した。深層項筋群への注射は第三頸椎 の高さで注射針を刺し，第二頸椎椎弓を探りその位置 でプロカインを片側 $1.5 \mathrm{cc}$ 宛，両側，計 $3.0 \mathrm{cc}$ を注射し た.

メチレン 青を混じたプロカイン溶液を上述の方法 で，ウサギの頸筋に注射した予備実験の結果，次ぎの ことが判明している，イ，浅層項筋群への注射では， M. splenius, M. trapezius の一部が青染される. 口)， 深層項筋群への注射では, M. rectus capitis dorsalis major et. minor, M. obliques capitis inferior の大部分 とM. transverso-occipitalis の一部が青染される. 勿論, メチレン青の分子の大きさとプロカインのそれとは異 なるので，メチレン青で染色された部位のみがプロカ インの浸潤をうけているとは厳密の意味ではいい得な い.しかし，メチレン青で染められた部分が主として プロカインの浸潤をうけた部分と考えてよいと思う.

因みに，この方法では側頸部にメチレン青が及ぶこと はなく（從つて，頸部交感神経はこの方法によつて著 明な影響をうけないと考えられる)。また関節䨢や後根 線維，および脊髄は青染されることはない，従つて， これらの部位はプロカインの著明な浸潤をうけないも のと考えられる。

なお，Bosによるとプロカインを直接脊髄後索に与 てがうと動物は呼吸困難をきたし，窒息死するという $\left(\mathrm{Bos}^{3)}\right)$ 。筆者の実験では，このような事態は全くみ なかつたので上述の方法で脊髄知覚神経や脊髄そのも のが侵されることはないと考えている。ただし，関節 囊からの求心性線維は, 最近の研究では, 骨格筋内を 通過するといわれているので，上述の方法でプロカイ ンが注射された場合, 頸筋内の 深部受容器の 機能が Damage の状態に樎るのみでなく, 関節㐮からの求心 性線維の一部も，その機能が障害されることを否定し 得ない。しかし，寺山が述へててるように頸部の関節 とは直接関係のない胸鎖乳突筋にプロカインを注射し ても，視性反射は明白な影響をうけること（寺山 ${ }^{37)}$ )， 
および桧，黒沢の報告しているように正常人の胸鎖乳 突筋にプロカインを注射しても眩暈を生じ平衡失調を 来す事実を合せ考えると(桧，黒沢 ${ }^{23)}$ )，この方法によ るプロカイン注射で，視性反射の変化が起るのは，や はり頸筋群内に分布する $\gamma$ 線維が影響をうけ，その機 能を低下するためのものと考えてよいと思う.

ところで(3)，で述べたように実験当初にはこの動物 に $1 \%$ プロカイン $3.0 \mathrm{cc}$ 注射し，30日間に全量 $45.0 \mathrm{ccc}$ プロカインが投与された場合，動物の全身状態が変化 するのではないかとの懸念がもたれた。しかし，予備 実験の結果, 被検動物の体重が著しく減少したとか， また，その視性反射が著しく変化を来したとかの兆候 はみられなかつた。従つて, プロカイン頸筋内注射の 条件下で行つた視性訓練による視運動刺邀適応性向上 が，その動物の頸筋正常時のそれに比較し，不良であ つたとしても，これはプロカインの全身的中毒に由来 するのではなく，視性訓練時頸部に注射したプロカイ ンにより，その部の深部受容器の機能が低下している ことが，その主因をなすものと考えたい．

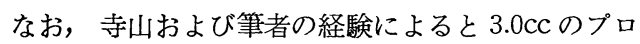
カインを, 頸部項筋群に注射して最も効果的に視性反 射が抑制されるのは，注射後約10分から 30 分までであ り，またプロカインの影響は約 2 時間で，ほ淮消失す る. 従つて, 毎回の視性訓練はプロカイン注射後10分 目から行なわれている。 なお, 視性訓練効果は最後の 視性訓練(15回目)後24時間目に測定されているので, プロカインの影響はもはや消失しているものと考えた い.

\section{(6) 視性訓練の方法;}

すでに，この項についてはその一部を項目(4)で述へ ている，従つて，重複する籄所は省略する。ここで行 なつた視性訓練には被検動物の頸筋に何等の操作を加 えない状態で訓練する場合(この方法を Ist. method of training と呼ぶ) と, この同じ動物の頸筋にプロカイン を注射し，同じ視運動刺激反覆を加えて訓練する場合 (2nd. method of trainingと呼ぶ)があり両訓練間には， 凡そ，1 力月間の間隔をおいている，なお，この実験 では, 先ず 1 st. method of training を行い. 次いで， 2nd, method of training を行なつた.このような順序 で訓練を行なつた理由は次ぎの事実に基ずいている。 すなわち，福田，桧らの報告によると多くの動物で は，視性訓練を重るる程，訓練効果はより早く，より 高度に得られる。 したがつて, 2nd, method of training を先きにし，1 st, method of training を後で行なう場合
には，訓練を重ねた故に，頸筋正常の際に，より有効 に視運動刺激適応性向上が得られたという懸念が生ず る.したがつて，原則として，1st, method of training を行ない，次いで 2 nd, method of training を行なつ た. 因みに，2〜3の動物では，この順序を逆にして 訓練してみたが，この場合でも原則的にその成績は同 じ傾向を示した。したがつて，後述するような成績を 得た主なる原因は訓練方法の順序の問題ではないと考 える.

\section{（7）実 験 成績；}

実験は 2 つの群に分けられる. 実験 Iは深層項筋群 にプロカインが注射され，その条件下に行なわれた視 性訓練による視性反射の変化が，その動物の頸筋が正 常であつた際の，それと比較されるものである．実験 IIは浅層項筋群にプロカインが注射され，その条件下 に行なわれた視性訓練による視性反射の変化が，その 動物の頸筋が正常であつた際の，それと比較される実 験である．以下， 2 つの項目に分けて，その成績を述 べることとする。

\section{1）実験 Iで得られた成績；}

用いた動物は 4 羽であるが，原則的に同一の傾向を 示したので，ここでは代表例を詳細に申し述へ，その 他の例は視性眼振と視性頭振の変化を表示したい. 視 性脊喵反射は頭振の他に頭部の偏倚もみられる。しか し，この表では頭振を脊髄反射を代表として選んだ。 この理由は桧, 寺山の実験によると視性頭振は視性眼 振の発来を促進し, 視器の外界一の適応を増長する作 用を有するものであり，その出現の増加は動物の視性 平衡機能の向上を表明し得ることが判明しているから である. (Hinoki and Terayama ${ }^{16)}$ ). なお, 視性眼振 および視性頭振の記載は次ぎの方法によつた。すなわ ち，視性頭振，視性眼振が視性訓練により，ぞのよう に変化するかを表示するに当つては, 初速 $0 \circ$ より最 高速 $160^{\circ} / \mathrm{sec}$ までの円筒回転により起る視性反射の経 過を便宣上，20秒ごとに 8 つの Zone に分け，その各 々で得られた視性頭振および視性眼振数を記載するこ とにしている。 また，視性眼振の視性訓練による変化 を明示するためには，グラフでこれを表わす試みもし た。すなわち, 横軸に円筒回転速度を, 縦軸には上述 の8つのZoneの各乃に表われる視性眼振数を記入する ことにした（図 6, 7,12,13参照)
a）ウサギNo. 1 における視性訓練による視性反射 の変化；
i), 訓練前 (1st. method of training). 
円筒右まわし；図(2)に示したように円筒を右まわし すると，頭部は右に中等度に偏倚し，その位置より左 一粗大な頭振を発来する。しかし，円筒回転速度が $42 \%$ sec を越えて速くなると動物は頭部を軽度に右に 偏倚したまま頭振を示さない。160秒間の頭振数は 9 打である. 視性眼振は円筒の回転速度が $40^{\circ} / \mathrm{sec}$ まで は振巾小であるが，比較的明膫に出現している．円筒 回転速度がこれ以上に速くなると眼振が 減少し初め $48^{\circ} / \mathrm{sec}$ 以上では出現しない. 160秒間の眼振数は 14 打 である。

円筒左まわし；円筒を左にまわすと，頭部は左に中 等度偏倚し，その位置より右へ粗大な頭振を発来す る. しかし，円筒回転速度が $60^{\circ} / \mathrm{sec}$ を越えて速くな ると，動物の頭部は，ほほ正中位にとどまり頭振の発 来をみない，160秒間の頭振数は 5 打である，視性眼 振は 視性円筒回転速度が $40^{\circ} / \mathrm{sec}$ までは振巾小である が, 比較的明瞭に出現している. しかし, 円筒回転速 度がそれ以上に速くなると，眼振は漸次減少しはじめ $60^{\circ} / \mathrm{sec}$ 以上では眼振を欠く. 160秒間の眼振数は 11 打 である。

\section{ii)，訓練15回目 (1st. method of training)}

円筒右まわし；図(3)に示したように円筒を右まわし すると，頭部はほほほ正中位をしめ，円筒回転が $27^{\circ} / \mathrm{sec}$ に達すると，その位置より左へ振币中等度の頭振を出 現し初める．頭振は円筒回転速度が $40 \%$ sec に達する までに 4 打出現しているが， 円筒の回転がそれ以上
速くなつても，頭振はなお出現し，円筒回転速度が $106 \%$ sec に達するまでに，更に6 打を加えている，し かし，これ以上円筒回転速度が速くなると，頭振の出 現は停止し，頭部は，注沽正中位にとどまつている。 160 秒間の 頭振数は10打である。視性眼振は円筒回転 速度が，100\% / sec に達するまでに，円筒回転速度が増 加すると共にその打数を増加している。 しかし，円筒 回転速度がそれ以上に速くなると，眼振は次第にその 数を減少する。 そして円筒回転速度が $136^{\circ} / \mathrm{sec}$ 以上に なると眼振を欠く．160秒間の眼振数は175打である。

円筒左まわし；円筒を左まわしすると，頭部は中等 度に左に偏倚し，その位置から右へ振巾大なる頭振が 出現する，頭振は円筒回転速度が $60^{\circ} / \mathrm{sec}$ に達するま でに 15 打出現しているが，円筒の回転速度がそれ以上 速くなると頭振の出現は少なくなる，しかし円筒回転 速度が $130^{\circ} / \mathrm{sec}$ に達するまでに，更に 4 打を加えてい る。そして円筒回転速度が，それ以上に速くなると頭 部を左に軽度偏倚したまま頭振を欠く１60秒間の頭 振数は19打である。

視性眼振は 円筒速度が $60^{\circ} / \mathrm{sec} に$ に達するまでは円筒 速度の増すと共にその打数を増加している．しかし， 円筒回転速度がそれ以上に速くなると眼振はその数を 減少し初め円筒回転速度が $155^{\circ} / \mathrm{sec}$. 以上になると眼振 をみなくなる１60秒間の眼振数は61打である.

iii), 訓練前 (2nd. method of training)

円筒右まわし；この動物を30日間，訓練を行なうこ

Change in optic reflexes induced by optic training .

Training was made on the rabbit with intact nuchol muscles.

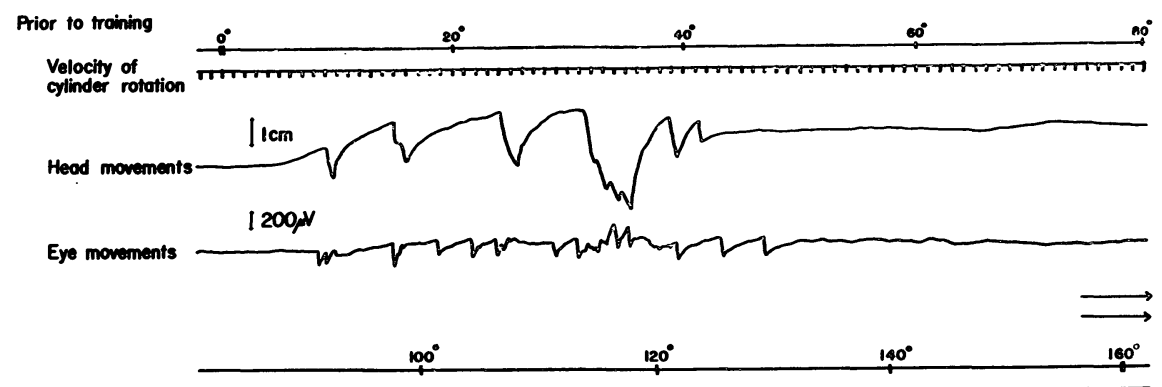

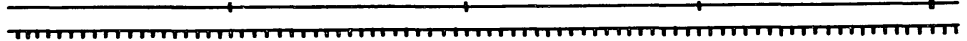

Fig. 2 
Change in optic reflexes induced by optic training .

Training was mode on the robbit with infact nuchal muscles.

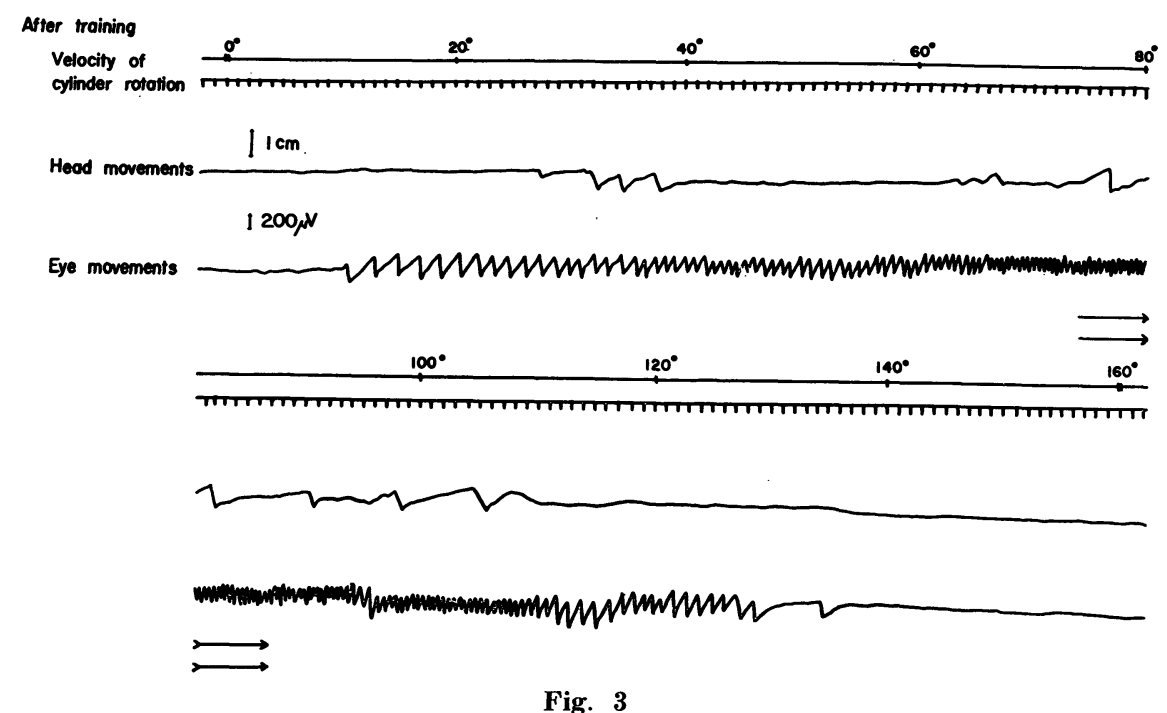

Change in optic reflexes induced by optic training.

Training wos mode on the robbli with the deep group of the nuchal muscles procainized.

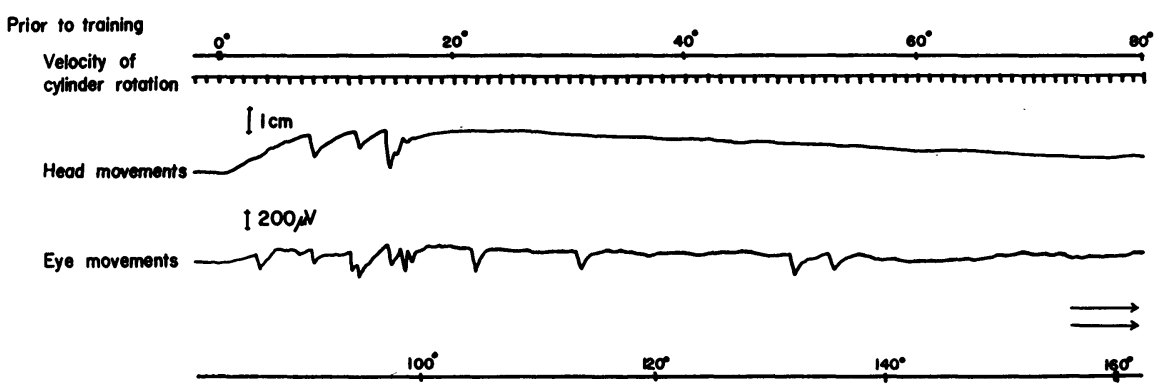

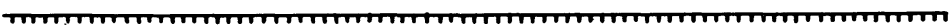

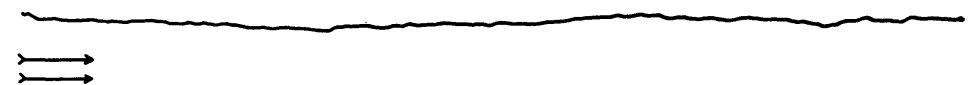

Fig. 4

となしに放置すると，頭振および眼振の出現は再び不 活潑となり，視性訓練前 (1st. method of training)の， それに近くなる。すなわち，図(4)に示したように，円 筒を右まわしすると，頭部は右に偏倚し，その位置よ り振巾中等度の左への頭振の発来を認める.しかし，
円筒回転速度が等 $17^{\circ} / \mathrm{sec}$ を越えて速くなると，頭部は 軽度に右に㴜倚したまま頭振を欠く１60秒間の頭振 数は 5 打である。視性眼振は, 円筒回転速度が $20^{\circ} / \mathrm{sec}$ に達するまでは，比較的明瞭にみられる。しかしこ れ以上円筒回転速度が速くなると，眼振の発来は散発 
的となり $54^{\circ} / \mathrm{sec}$ の速さになると眼振をみない.160秒 間の眼振数は11打である.

円筒左まわし；円筒を左にまわすと，頭部は左に軽 度偏倚し，その位置から振巾大なる右一の頭振を認め る. しかし，円筒回転速度が $40^{\circ} / \mathrm{sec}$ を越えて速くな ると，頭部はほほ正中位を保ち，頭振をみなくなる。 160 秒間の頭振数は 9 打である. 視性眼振は 振巾中等 で右に向い，円筒回転速度 $40^{\circ} / \mathrm{sec}$ までは比較的明瞭 にみられる。しかし，これ以上円筒回転速度が速くな ると，視性眼振は減少し初め $52^{\circ} / \mathrm{sec}$ 以上の高速円筒 回転では眼振をみない.160秒間の眼振数は 20 打であ る.

IV) 訓練15回目 (2nd. method of training)

円筒右まわし; 図(5)に示したように，円筒を右に まわすと，頭部は軽度に右に偏倚し，円筒回転速度が $15 \%$ sec に達すると，振巾小または中等度の 頭振を左 に出現し初める. しかし, 円筒回転速度が $63^{\circ} / \mathrm{sec}$ を 越えて, 速くなると, 頭部は, ほほ正中位をとり, 頭 振は消失する。160秒間の頭振数は13打である，視性 眼振は振巾中等度で左へ向い, 円筒回転速度が $54^{\circ} / \mathrm{sec}$ までは比較的規則正しく出現している，しかし，円筒 回転速度がそれ以上速くなると, 眼振の出現は著しく 不良となり $74^{\circ} / \mathrm{sec}$ を越えると消失する，160秒間の眼 振数は27打である.

円筒左まわし；円筒を左にまわすと，頭部は軽度に
左に偏倚し，円筒回転速度が $14 \%$ sec に達する振巾小 なる頭振を右一出現し初める。しかし，円筒回転速度 が $45 \%$ sec を越えて速くなると頭部は，ほほ正中位を とり，頭振の出現はみられなくなる１60秒間の頭振 数は 3 打である. 視性眼振は振巾中等度で右に向い， 円筒回転速度 $45^{\circ} / \mathrm{sec}$ までは，規則正しく出現してい る.しかし，冈筒回転速度がそれ以上速くなると眼振 の出現は減少し初め $60^{\circ}$ /sèc 以上では眼振をみない. 160 秒間の眼振数は 33 打である.

以上の成績を小括すると次ぎのようになる.

(i) 視性訓練により視性頭振は，円筒回転速度が より高速になつて発現する傾向を示す．また，視性眼 振は円筒回転速度が増すにつれて増大し，訓練前には， その動物が適応できなかつた高速の視性円筒回転にも 活潑に視性眼振を発来して庥答するようになる。

（ii）訓練を中止すると，視性頭振，および視性眼 振の発現は不活潑となり，訓練前のそれに類似するよ うになる。このような動物の樑層項筋にプロカインを 注射し，その条件下に同じ視性訓練を再度行なう場合， 視性頭振および視性眼振には（i）で述べた傾向が表わ れる。しかし，その程度は低い。

(iii) 視性訓練による視性眼振の発来状況の変化を 明らかにするために上述した方法で 160秒間の視性眼 振発来経過を20秒毎に8つの zoneに区分して，各々の zoneに出現する視性眼振数を記入すると，図(6), (7)の

Change in optic reflexes induced by optic training.

Training was made on the rabbit with the deep group of the nuchal muscles procainized.

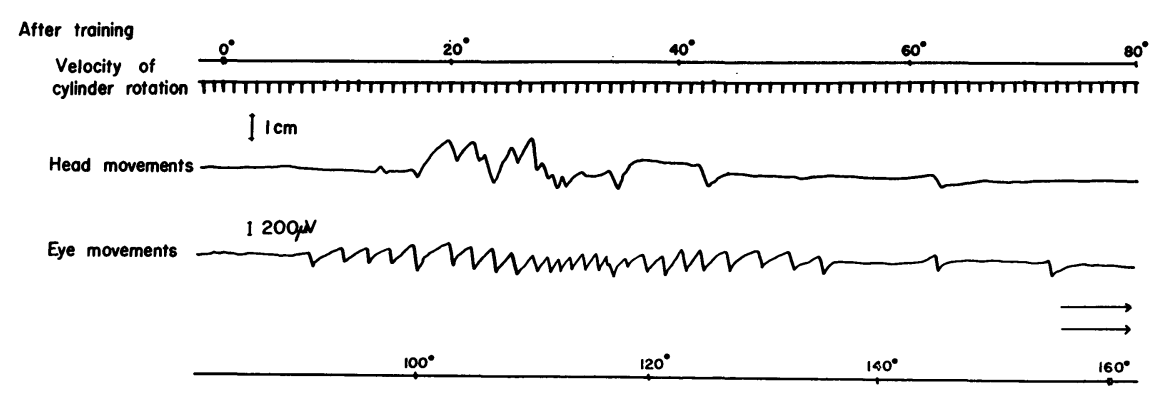

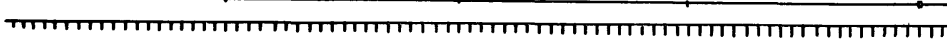

Fig. 5 


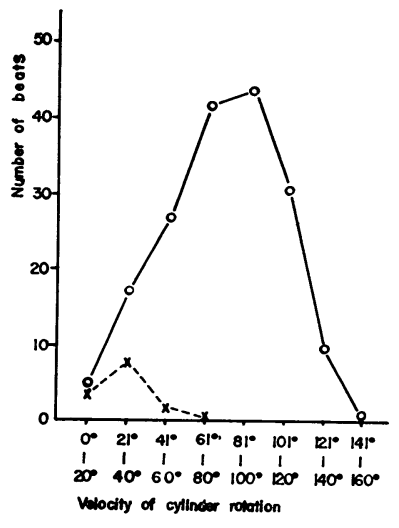

(Nuchal muscles: infact)

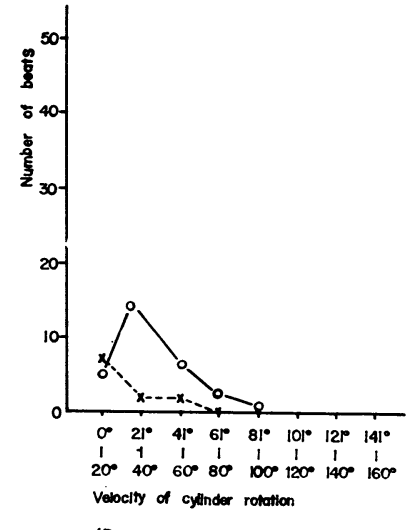

(Deep group: procainized)

(Cylinder rotation: to right)

Fig. 6

Change in optic eye nystagmus induced by optic training.

Training was made on the rabbit(No.l) under the following two different conditions.
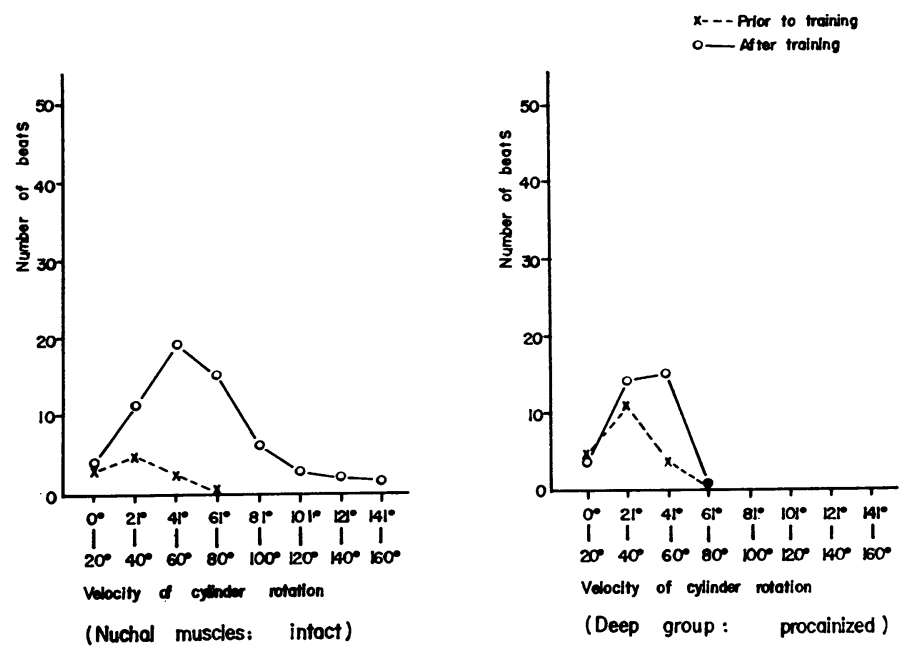

(Cylinder rotation: to left)

Fig. 7

如くなる。これらの図より次の事が判る，イ）視性訓 練により，視性眼振には response increase が起こり， 視性円筒の高速回転にも，動物はよく応答するように

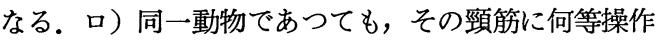
を加えないで訓練する場合，すなわち，1st. method of training でおこる response increase は2nd. method of training で起こるそれに優つている.

b）その他のウサギにおける成績；
その他の動物，すなわち，No. 2 ～No. 4 の成績を 表 (1)，(2)，(3)に示してある. 細部に亘つては視運動刺 激適応性獲得状況に差異がある。しかし，各々の成績 はN No. 1 で得られた成績と原則的に一致している。従 つて, 深層項筋群は, 視器に協力して, 視性訓練効果 獲得に際して，重要な役割を果すことが，この表より 明かである。

2）実験IIで得られた成績 : 
Table 1 (Rabbit : No. 2)

\begin{tabular}{|c|c|c|c|c|c|c|c|c|c|c|c|}
\hline Method & training & $\begin{array}{l}\text { Direction of } \\
\text { cylinder } \\
\text { rotation }\end{array}$ & Nystagmus & ${\stackrel{2}{0^{\circ}}}^{0}$ & $\stackrel{21}{\circ}_{40^{\circ}}^{\circ}$ & $\stackrel{4}{2}_{60^{\circ}}^{\circ}$ & $\begin{array}{l}61^{\circ} \\
{ }^{2} \\
80^{\circ}\end{array}$ & ${ }_{100^{\circ}}^{81^{\circ}}$ & ${\stackrel{1}{101^{\circ}}}_{120^{\circ}}$ & $\stackrel{121^{\circ}}{?}{ }_{140^{\circ}}^{\circ}$ & $\stackrel{14}{1}^{\circ}$ \\
\hline \multirow{8}{*}{ 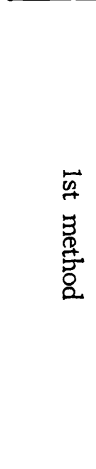 } & \multirow{4}{*}{$\begin{array}{l}\text { before } \\
\text { training }\end{array}$} & \multirow{2}{*}{ to right } & head nysta. & 1 & 5 & 2 & 0 & 0 & 0 & 0 & 0 \\
\hline & & & eye nysta. & 1 & 5 & 2 & 0 & 0 & 0 & 0 & 0 \\
\hline & & \multirow{2}{*}{ to left } & head nysta. & 4 & 2 & 0 & 0 & 0 & 0 & 0 & 0 \\
\hline & & & eye nysta. & 2 & 4 & 0 & 0 & 0 & 0 & 0 & 0 \\
\hline & \multirow{4}{*}{$\begin{array}{c}\text { after } \\
\text { training }\end{array}$} & \multirow{2}{*}{ to right } & head nysta. & 2 & 3 & 2 & 1 & 1 & 1 & 0 & 1 \\
\hline & & & eye nysta. & 13 & 26 & 19 & 17 & 32 & 21 & 20 & 3 \\
\hline & & \multirow{2}{*}{ to left } & head nysta. & 3 & 3 & 0 & 1 & 0 & 0 & 0 & 0 \\
\hline & & & eye nysta. & 9 & 12 & 17 & 8 & 6 & 5 & 4 & 1 \\
\hline \multirow{8}{*}{ 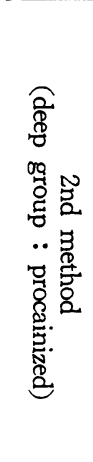 } & \multirow{4}{*}{$\begin{array}{l}\text { before } \\
\text { training }\end{array}$} & \multirow{2}{*}{ to right } & head nysta. & 0 & 0 & 0 & 0 & 0 & 0 & 0 & 0 \\
\hline & & & eye nysta. & 4 & 8 & 3 & 0 & 0 & 0 & 0 & 0 \\
\hline & & \multirow{2}{*}{ to left } & head nysta. & 1 & 2 & 0 & 0 & 0 & 0 & 0 & 0 \\
\hline & & & eye nysta. & 6 & 16 & 4 & 1 & 0 & 0 & 0 & 0 \\
\hline & \multirow{4}{*}{$\begin{array}{l}\text { before } \\
\text { training }\end{array}$} & \multirow{2}{*}{ to right } & head nysta. & 1 & 2 & 0 & 1 & 0 & 0 & 0 & 0 \\
\hline & & & eye nysta. & 11 & 10 & 9 & 2 & 0 & 0 & 0 & 0 \\
\hline & & \multirow{2}{*}{ to left } & head nysta. & 0 & 1 & 0 & 0 & 0 & 0 & 0 & 0 \\
\hline & & & eye nysta. & 7 & 11 & 7 & 3 & 1 & 0 & 0 & 0 \\
\hline
\end{tabular}

Table 2 (Rabbit : No. 3)

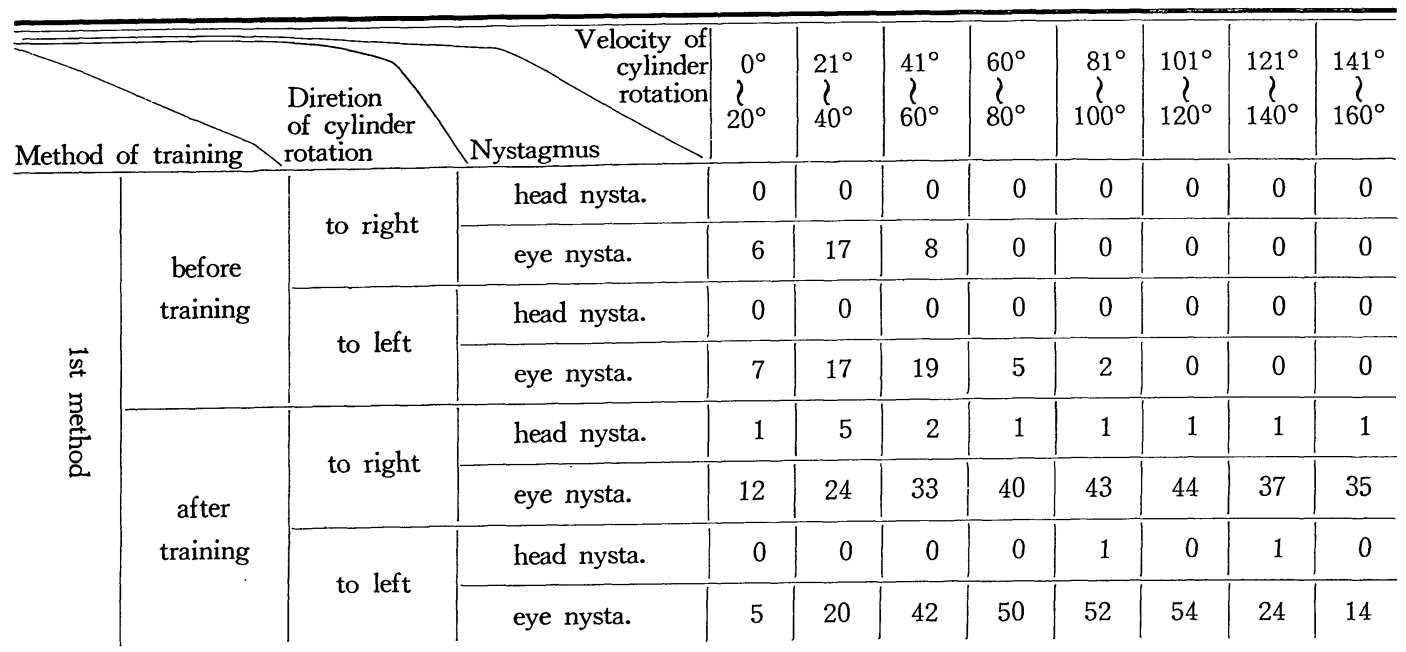




\begin{tabular}{|c|c|c|c|c|c|c|c|c|c|c|}
\hline \multirow{4}{*}{\begin{tabular}{c|c}
$\frac{\widehat{O}}{8}$ & before \\
$\frac{\delta}{8}$ & training
\end{tabular}} & \multirow{2}{*}{ to right } & head nysta. & 0 & 2 & 4 & 1 & 0 & 0 & 0 & 0 \\
\hline & & eye nysta. & 8 & 15 & 14 & 11 & 2 & 0 & 0 & 0 \\
\hline & \multirow{2}{*}{ to left } & head nysta. & 1 & 1 & 0 & 0 & 0 & 0 & 0 & 0 \\
\hline & & eye nysta. & 5 & 8 & 10 & 1 & 1 & 0 & 0 & 0 \\
\hline \multirow{4}{*}{$\begin{array}{l}\text { after } \\
\text { training }\end{array}$} & \multirow{2}{*}{ to right } & head nysta. & 1 & 2 & 0 & 0 & 0 & 0 & 0 & 0 \\
\hline & & eye nysta. & 8 & 19 & 31 & 27 & 6 & 1 & 0 & 0 \\
\hline & \multirow{2}{*}{ to left } & head nysta. & 0 & 0 & 0 & 1 & 1 & 0 & 0 & 0 \\
\hline & & eye nysta. & 8 & 24 & 37 & 49 & 44 & 25 & 0 & 0 \\
\hline
\end{tabular}

Table 3 (Rabbit : No. 4)

\begin{tabular}{|c|c|c|c|c|c|c|c|c|c|c|c|}
\hline \multicolumn{3}{|c|}{ Method of training $\begin{array}{l}\text { Direction } \\
\text { of cylinde } \\
\text { rotation }\end{array}$} & $\begin{array}{r}\begin{array}{r}\text { Velocit } \\
\text { cyl } \\
\text { rot: }\end{array} \\
\text { Nystagmus }\end{array}$ & $\begin{array}{c}0^{\circ} \\
20^{\circ}\end{array}$ & ${\stackrel{2}{21^{\circ}}}_{40^{\circ}}$ & $\begin{array}{l}41^{\circ} \\
60^{\circ}\end{array}$ & $\begin{array}{l}61^{\circ} \\
? \\
80^{\circ}\end{array}$ & $\stackrel{81}{8}^{\circ}$ & $\hat{1}_{120^{\circ}}^{\circ}$ & ${\stackrel{121^{\circ}}{l}}_{140^{\circ}}$ & ${\stackrel{14}{l^{\circ}}}^{\circ}$ \\
\hline \multirow{8}{*}{ 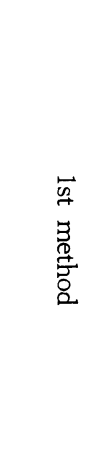 } & \multirow{4}{*}{$\begin{array}{l}\text { before } \\
\text { training }\end{array}$} & \multirow{2}{*}{ to right } & head nysta. & 0 & 1 & 0 & 0 & 0 & 0 & 0 & 0 \\
\hline & & & eye nysta. & 1 & 1 & 2 & 0 & 0 & 0 & 0 & 0 \\
\hline & & \multirow{2}{*}{ to left } & head nysta. & 1 & 0 & 1 & 1 & 0 & 0 & 0 & 0 \\
\hline & & & eye nysta. & 1 & 0 & 1 & 1 & 0 & 0 & 0 & 0 \\
\hline & \multirow{4}{*}{$\begin{array}{l}\text { after } \\
\text { training }\end{array}$} & \multirow{2}{*}{ to right } & head nysta. & 0 & 2 & 3 & 1 & 0 & 1 & 1 & 0 \\
\hline & & & eye nysta. & 8 & 31 & 38 & 34 & 28 & 30 & 25 & 16 \\
\hline & & \multirow{2}{*}{ to left } & head nysta. & 0 & 0 & 0 & 2 & 0 & 1 & 0 & 0 \\
\hline & & & eye nysta. & 4 & 17 & 12 & 11 & 14 & 8 & 5 & 3 \\
\hline \multirow{8}{*}{ 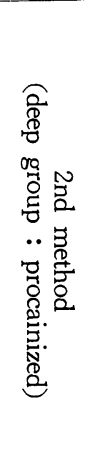 } & \multirow{4}{*}{$\begin{array}{l}\text { before } \\
\text { training }\end{array}$} & \multirow{2}{*}{ to right } & head nysta. & 0 & 0 & 0 & 0 & 0 & 0 & 0 & 0 \\
\hline & & & eye nysta. & 4 & 19 & 12 & 9 & 3 & 0 & 0 & 0 \\
\hline & & \multirow{2}{*}{ to left } & head nysta. & 0 & 0 & 0 & 0 & 0 & 0 & 0 & 0 \\
\hline & & & eye nysta. & 4 & 10 & 6 & 1 & 0 & 0 & 0 & 0 \\
\hline & \multirow{4}{*}{$\begin{array}{l}\text { after } \\
\text { training }\end{array}$} & \multirow{2}{*}{ to right } & head nysta. & 0 & 0 & 2 & 2 & 0 & 0 & 0 & 0 \\
\hline & & & eye nysta. & 11 & 25 & 37 & 9 & 0 & 0 & 0 & 0 \\
\hline & & \multirow{2}{*}{ to left } & head nysta. & 2 & 2 & 0 & 0 & 0 & 0 & 0 & 0 \\
\hline & & & eye nysta. & 4 & 10 & 17 & 18 & 7 & 0 & 0 & 0 \\
\hline
\end{tabular}

用いたウサギは 4 羽であるが原則的に同一の傾向を 示したのでここでは代表例を詳細に申し述へ，その 他の例は，視性眼振と視性頭振の変化を表示するにと どめたい.

a） ウサギ No. 5 における視性訓練による視性反射 の変化； i) 訓練前 (1st. method of training)

円筒右まわし；図(8)に示したように，円筒を右まわ しすると頭部は軽度に右に偏倚したまま，頭振の発来 をみない，視性眼振は振巾小で左に向い，円筒回転速 度 $76^{\circ} / \mathrm{sec}$ までは散発的に出現する。しかし，それ以 上円筒回転速度が 速くなると眼振は出現しない. 160 
Change in optic reflexes induced by optic training
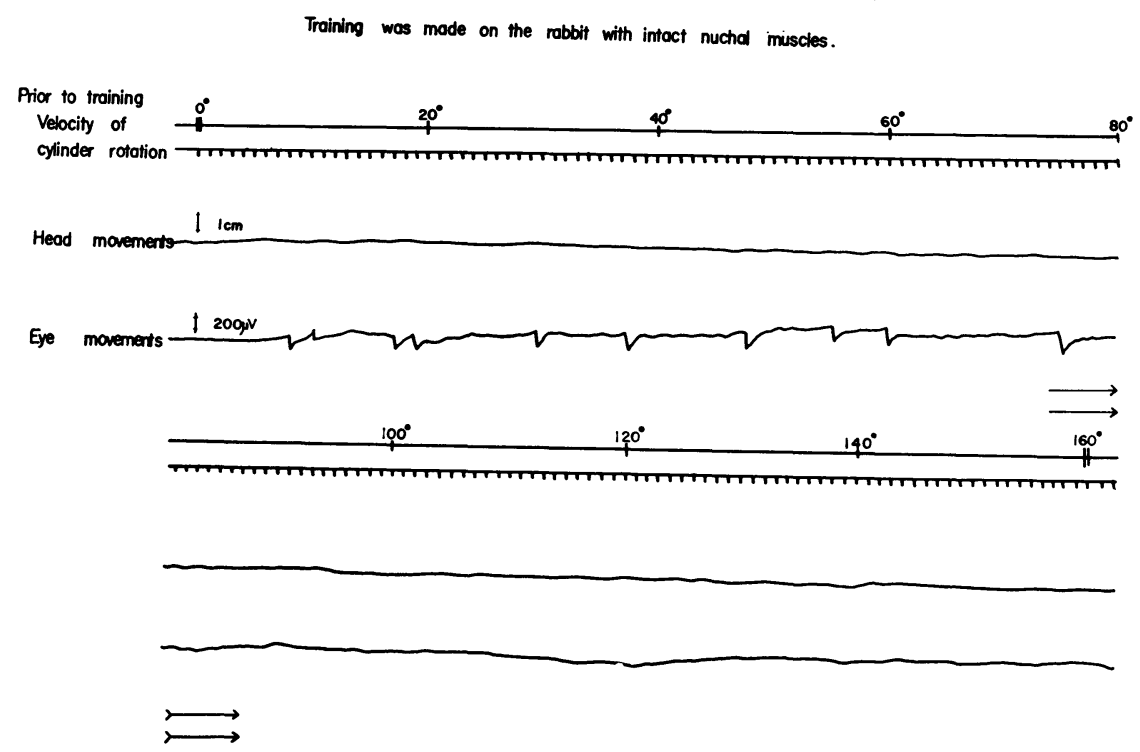

Fig. 8

秒間の眼振数は10打である.

円筒左まわし；円筒を左まわしすると，頭部は軽度 左に偏倚し，その位置から右への振巾中等度の頭振を 発現する．しかし，円筒回転速度が $17 \%$ sec を越えて 速くなると，頭部は，ほほ正中位をとり，頭振の発来 をみなくなる１60秒間の頭振数は 2 打である．視性 眼振は振巾中等度で右へ向い，円筒回転速度 $15 \%$ sec までは比較的良好に出現するが，以後散発的となり $31 \% \mathrm{sec}$ 以上では眼振を欠く．160秒間の眼振数は 4 打 を数えるのみである.

ii) 訓練15回目 (1st. method training)

円筒右まわし；図(9)に示したように円筒を右まわし すると，頭部は，ほほ 正中位をとり円筒回転速度が $18^{\circ} / \mathrm{sec}$ に達すると振巾大なる 頭振が 左へ発来し初め $70 \%$ sec までは，比較的活潑に発現する．それ以上円 筒回転速度が速くなると頭振の出現は散発的となるが $160 \%$ sec においても，なお頭振をみる，160秒間の頭 振数は24打である. 視性眼振は円筒回転速度が増大す るにつれて，その打数を増し円筒回転速度が $160^{\circ} / \mathrm{sec}$ に達しても，なお眼振は消失しない. 160 秒間の眼振 数は69打である。

円筒左まわし；円筒を左にまわすと，頭部は左に偏 倚し，その位置から 振巾大なる右への頭振が出現す る、円筒回転速度が $120 \%$ sec まで頭振が活潑に出現す
る、しかし，それ以上に円筒回転速度が速くなると頭 振の出現は散発的となり，140以上の円筒回転速度で は頭振をみない. 160 秒間の頭振数は27打である。視 性眼振は振巾小または中等度で右へ向い円筒回転速度 が $100 \% / \mathrm{sec} に$ に達するまでは，円筒回転速度の増大と共 にその打数を増す。しかし，円筒回転速度がそれ以上 速くなると眼振の発現は減少し初め $144^{\circ} / \mathrm{sec}$ 以上にな ると眼振は消失する。160秒間の眼振数は49打である.

iii) 訓練前 (2nd. method of training)

円筒右まわし；この動物を30日間，訓練を行なうこ となく放置すると, 視性頭振, 視性眼振の発来は共に 不活潑となり，訓練前 (1st. method of training)のそ れに近ずく、すなわち，図(10)に示したように，円筒を 右まわしすると，頭部は軽度右に偏倚するが頭振は発 現しない. 視性眼振は振巾中等度で左に発現するが， 散発的で円筒回転速度が $51^{\circ} / \mathrm{sec} に$ 達するまでに 3 打 をみるのみである，そして，それ以上円筒回転速度が 速くなると眼振は出現しない. 160秒間の眼振数は3打 である。

円筒左まわし；円筒を左まわしすると，頭部は軽度 左に偏倚し, その位置から振巾中等度の頭振を散発的 に発来する．円筒回転速度が $60 \% / \mathrm{sec}$ 以上になると，頭 振は停止し，頭部は，ほほ正中位をとる１60秒間の 頭振数は 5 打である. 視性眼振は振巾中等度で右一向 
Change in optic reflexes induced by optic training.

Troining wos mode on the rabbit with intact nuchat muscles.

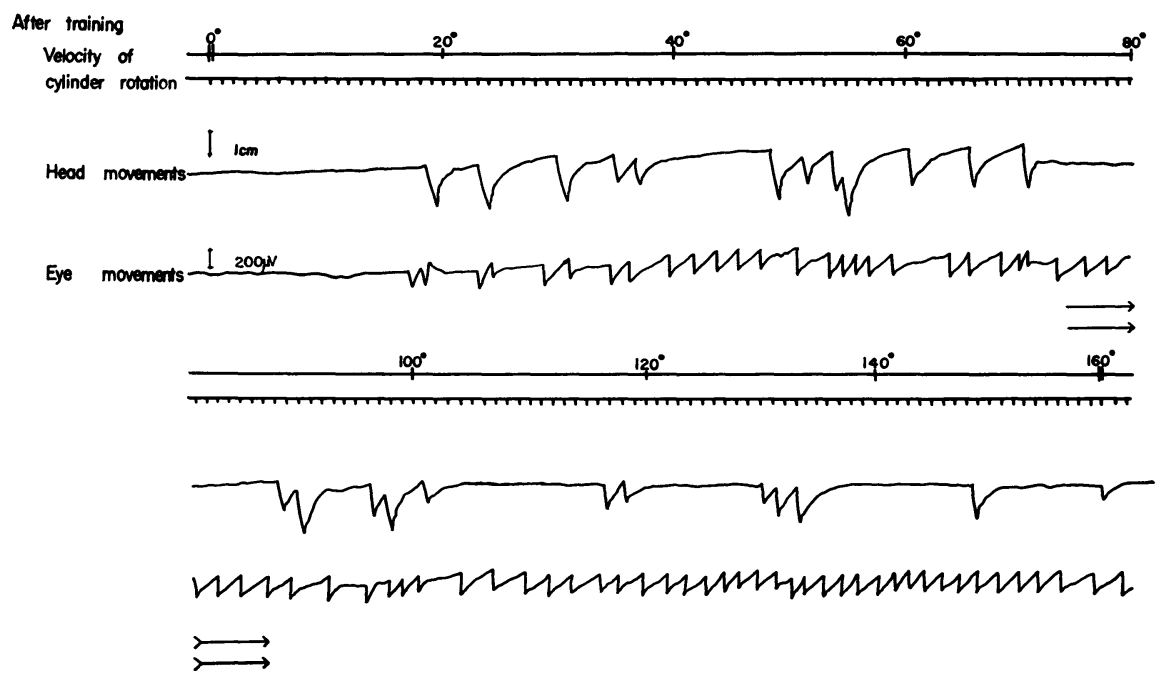

Fig. 9

Change in optic reflexes induced by optic training

Training was made on the rabbit with the superficial group of the nuchal muscles procoinized.

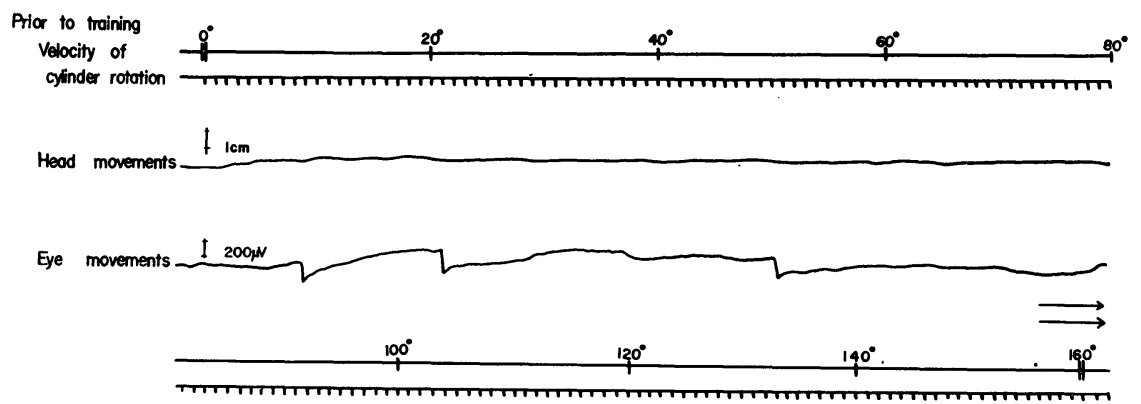

Fig. 10

い, 円筒回転速度が $20^{\circ} / \mathrm{sec}$ までは，比較的明瞭に出 現する．しかし，それ以上に円筒回転速度が速くなる と，眼振の発現は著しく不良となり，80\% $/ \mathrm{sec}$ 以上の 円筒回転では眼振をみない. 160 秒間の眼振数は 7 打 を数えるのみである。 iv) 訓練15回目 (2nd. method of training)

円筒右まわし；図(11)に示したように，円筒を右にま わすと，頭部は，ほほ正中位をとる．円筒回転速度が $37^{\circ} / \mathrm{sec}$ に達すると，左への振巾大なる頭振が出現し 初める。そして，円筒回転速度が $80^{\circ} / \mathrm{sec} に$ に達するま 
Change in optic reflexes induced by optic training.

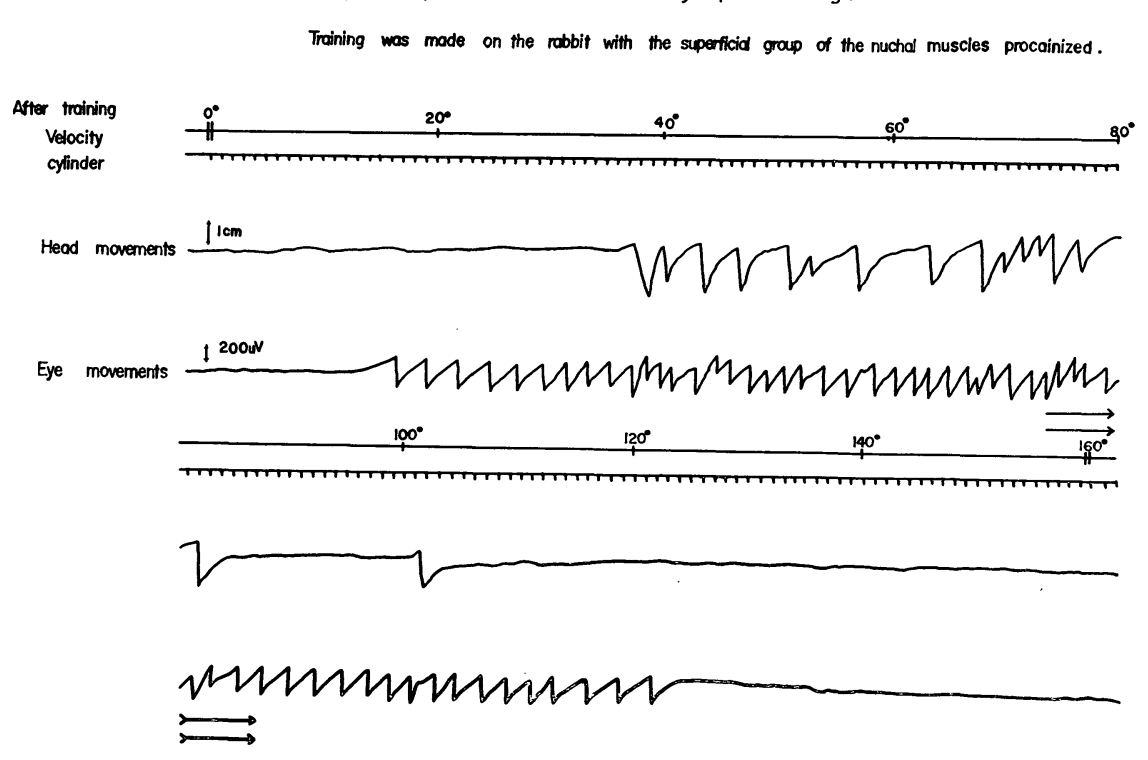

Fig. 11

でその状態が続くしかし，それ以上の高速回転で は，頭浱の出現は散発的となり，100\% $/ \mathrm{sec}$ 以上では頭 振を欠く 160 秒間の頭振数は16打である。視性眼振は 振巾中等度で左へ向い円筒回転速度が増大すると共に その打数も増加する．しかし円筒回転速度が $80^{\circ} / \mathrm{sec}$ 以 上に達すると，眼振はその打数を減少し初め $122 \% \mathrm{sec}$ 以上の高速円筒回転に対しては眼振をみとめなくな る. 160 秒間の眼振数は57打である.

円筒左まわし；円筒を左にまわすと，頭部は軽度左 に偏倚する，円筒回転速度が $30 \%$ sec に達すると，振 巾中等度の頭振が出現し初め, 円筒回転速度の増大と 共に，その振巾と·打数を増加する．しかし，円筒回 転速度が， $100^{\circ} / \mathrm{sec}$ 以上になると頭振が減少し 初め $115 \%$ sec 以上になると，頭振の発現は止む。 160秒間 の頭振数は13打である．視性眼振は振巾中等度で右一 向い，円筒回転速度の増大につれて眼振数を増す。し かし円筒回転度が $100 \%$ sec 以上になると，眼振数は減 少し初め $115 \%$ sec以上になると，眼振は消失する，160 秒間の眼振数は31打である.

以上を小括すると次ぎのようになる。

(i) 浅層項筋群にプロカイン注射を行なつた場合 でも，視性訓練により，イ）視性眼振の response increase が起こる．また，視性頭振は訓練前のそれに比 して，より高速の視性円筒回転に対して現われ初め， かつ，比較的高速の視性円筒回転に対しても消失しな
い.ロ）しかし，ウサギの頸筋に何等操作を加えない で訓練を行なつた場合と，浅層項筋にプロカインを注 射して行なつた場合とを比較すると，前者では，更に 高速の円筒回転に対して，頭振，眼振を発現しうる.

(ii）視性訓練による視性眼振の 変動を明らかにす るため，上述した分析方法を用いて眼振の変動を図示 すると，図(12)，(13)のような結果が得られた。即ちイ) 視性訓練により視性眼桭の response increaseが起こり， 動物は訓練前，明白に㢈答し得なかつた高速の円筒回 転にもよく応ずるようになる、ロ）この現象は，頸部 に何等操作を加えない場合でも，浅層項筋群にプロカ インを注射した場合でも，共に成立する。しかし，前 者の場合は後者の場合と比し，この現象の成立がより 明白である。

b）その他の動物における成績；

その他の動物 No.6 No. 8 のウサギでも，代表例 No. 5 で得られた成績と原則的に一致した成績が得ら れた（表(4)，(5)，(6)）そして，これらの成績を表(1)， (2)，(3)，に示した成績と比較する場合，浅層項筋群プ ロカイン注射時の訓練による視運動刺激適応性向上 は，深層項筋群プロカイン注射時のそれに比して良好 であるような印象をうける，勿論，この結論を更に確 実にするためには，イ）頸部に何等操作を加えない場 合の視運動刺激適応性向上の状況と， 口）深層項筋群 および浅層項筋群に，それぞれプロカロンを注射した 
Change in optic eye nystagmus induced by optic training Troining was made on the rabbif(No5) under the following two different conditions.
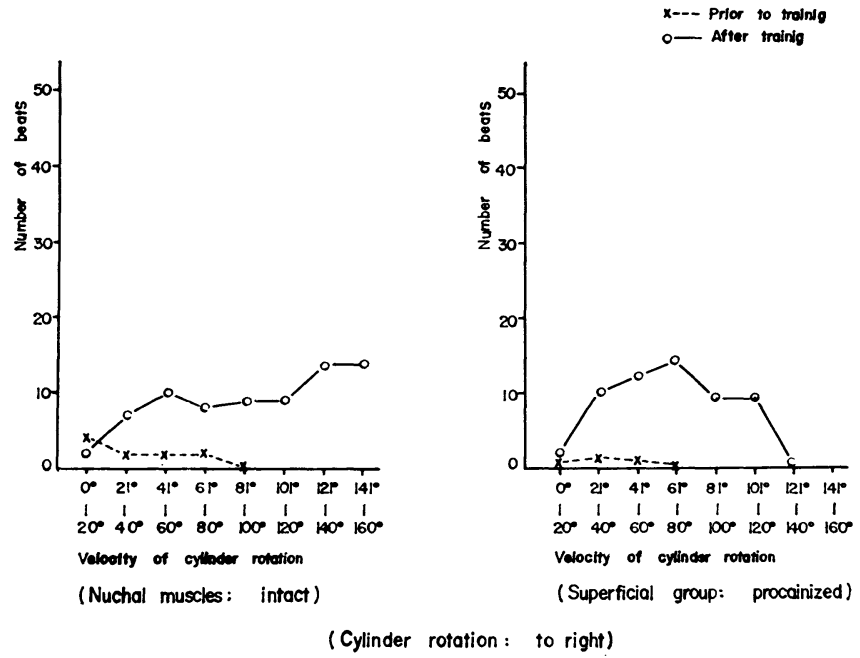

Fig. 12

Change in optic eye nystagmus induced by optic training . Training was made on the rabbit (No5) under the following two different conditions.

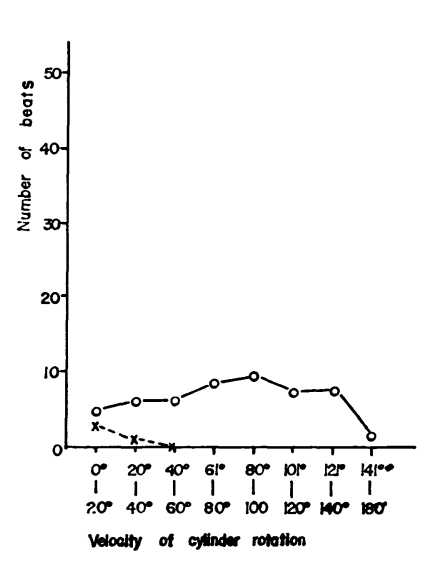

(Nuchal muscles: intact)

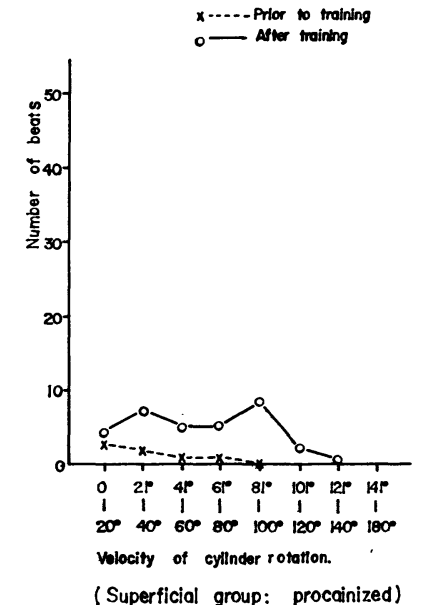

to left)

Fig. 13 
Table 4 (Rabbit : No. 6)

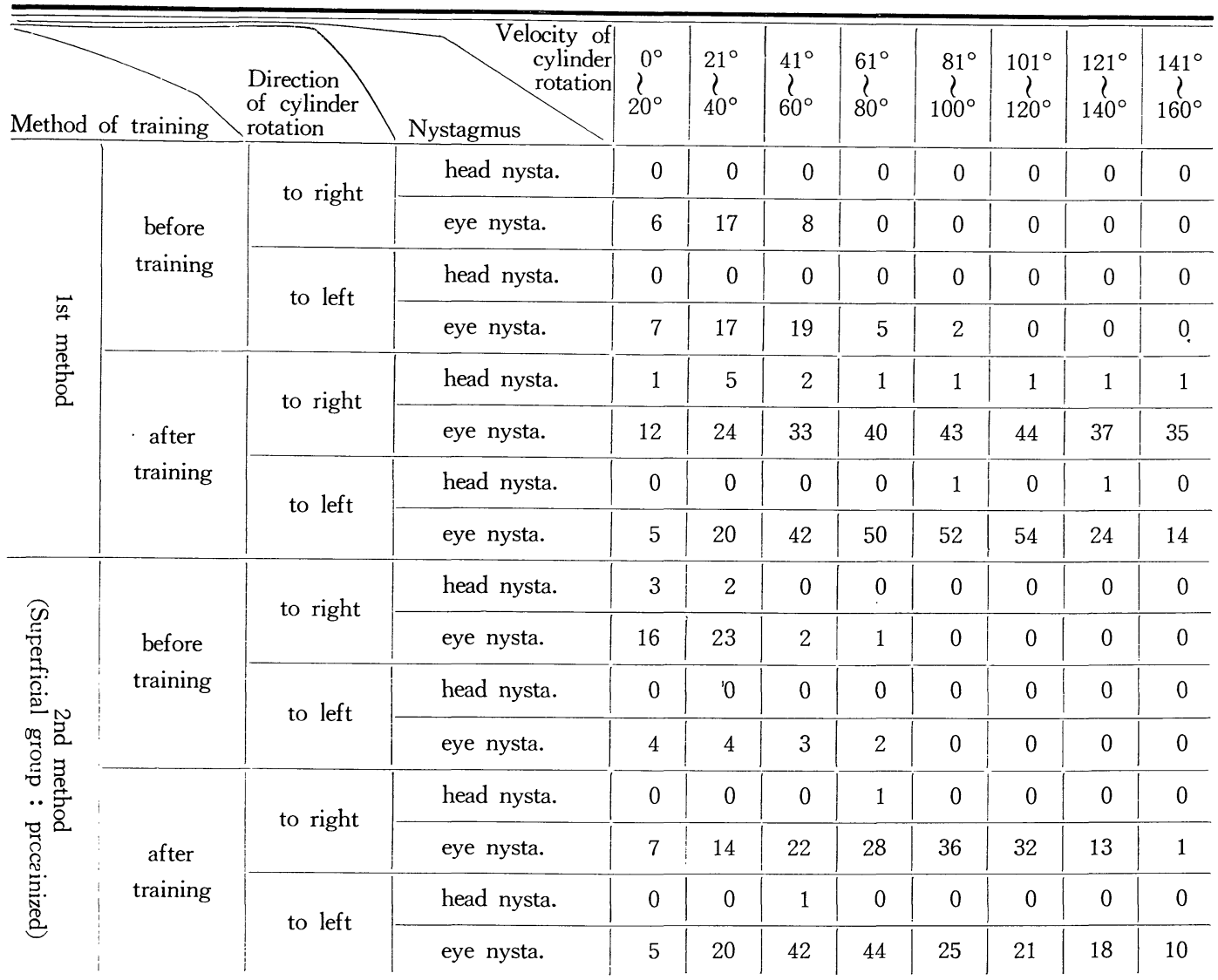

Table 5 (Rabbit : No. 7)

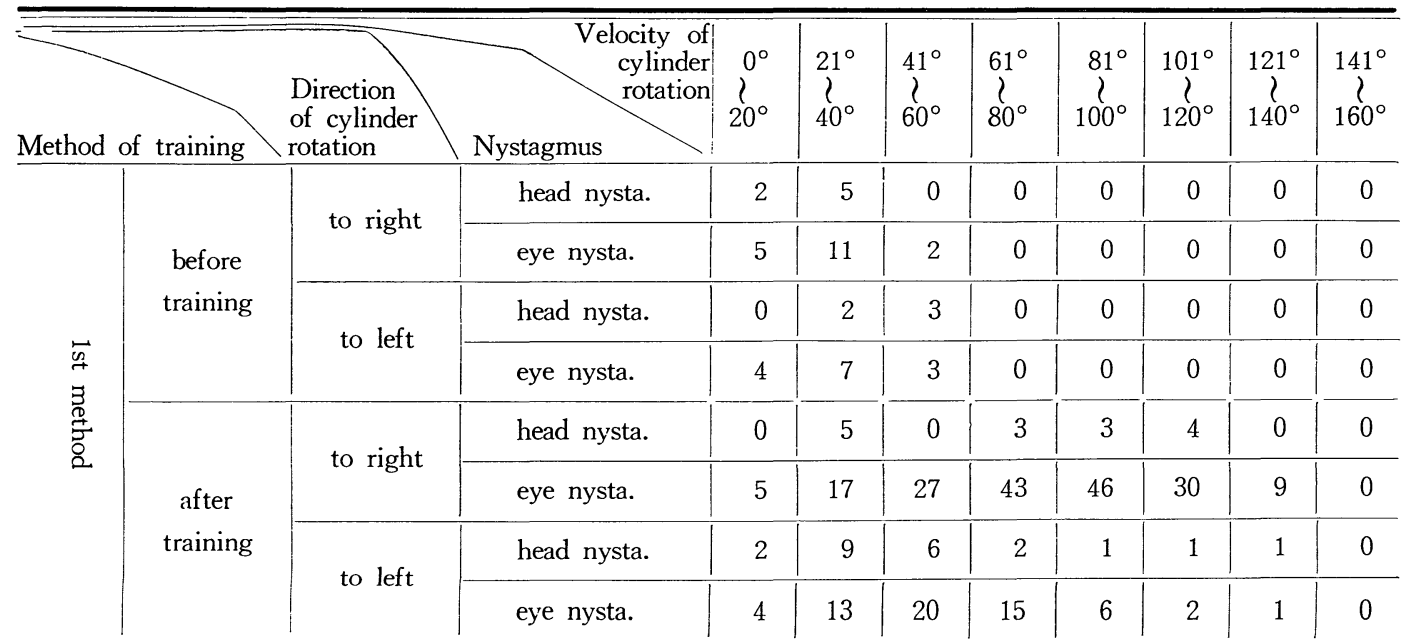




\begin{tabular}{|c|c|c|c|c|c|c|c|c|c|c|c|}
\hline \multirow{3}{*}{ 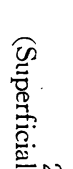 } & \multirow{4}{*}{$\begin{array}{c}\text { before } \\
\text { training }\end{array}$} & \multirow{2}{*}{ to right } & head nysta. & 1 & 4 & 2 & 0 & 0 & 0 & 0 & 0 \\
\hline & & & eye nysta. & 3 & 8 & 3 & 0 & 0 & 0 & 0 & 0 \\
\hline & & \multirow{2}{*}{ to left } & head nysta. & 2 & 5 & 0 & 0 & 0 & 0 & 0 & 0 \\
\hline \multirow{5}{*}{ 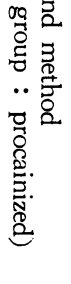 } & & & eye nysta. & 2 & 7 & 2 & 0 & 0 & 0 & 0 & 0 \\
\hline & \multirow{4}{*}{$\begin{array}{c}\text { after } \\
\text { training }\end{array}$} & \multirow{2}{*}{ to right } & head nysta. & 0 & 3 & 3 & 2 & 4 & 2 & 0 & 0 \\
\hline & & & eye nysta. & 5 & 16 . & 26 & 41 & 46 & 12 & 1 & 0 \\
\hline & & \multirow{2}{*}{ to left } & head nysta. & 1 & 0 & 3 & 1 & 0 & 0 & 0 & 0 \\
\hline & & & eye nysta. & 4 & 19 & 22 & 17 & 4 & 1 & 0 & 0 \\
\hline
\end{tabular}

Table 6 (Rabbit : No. 8)

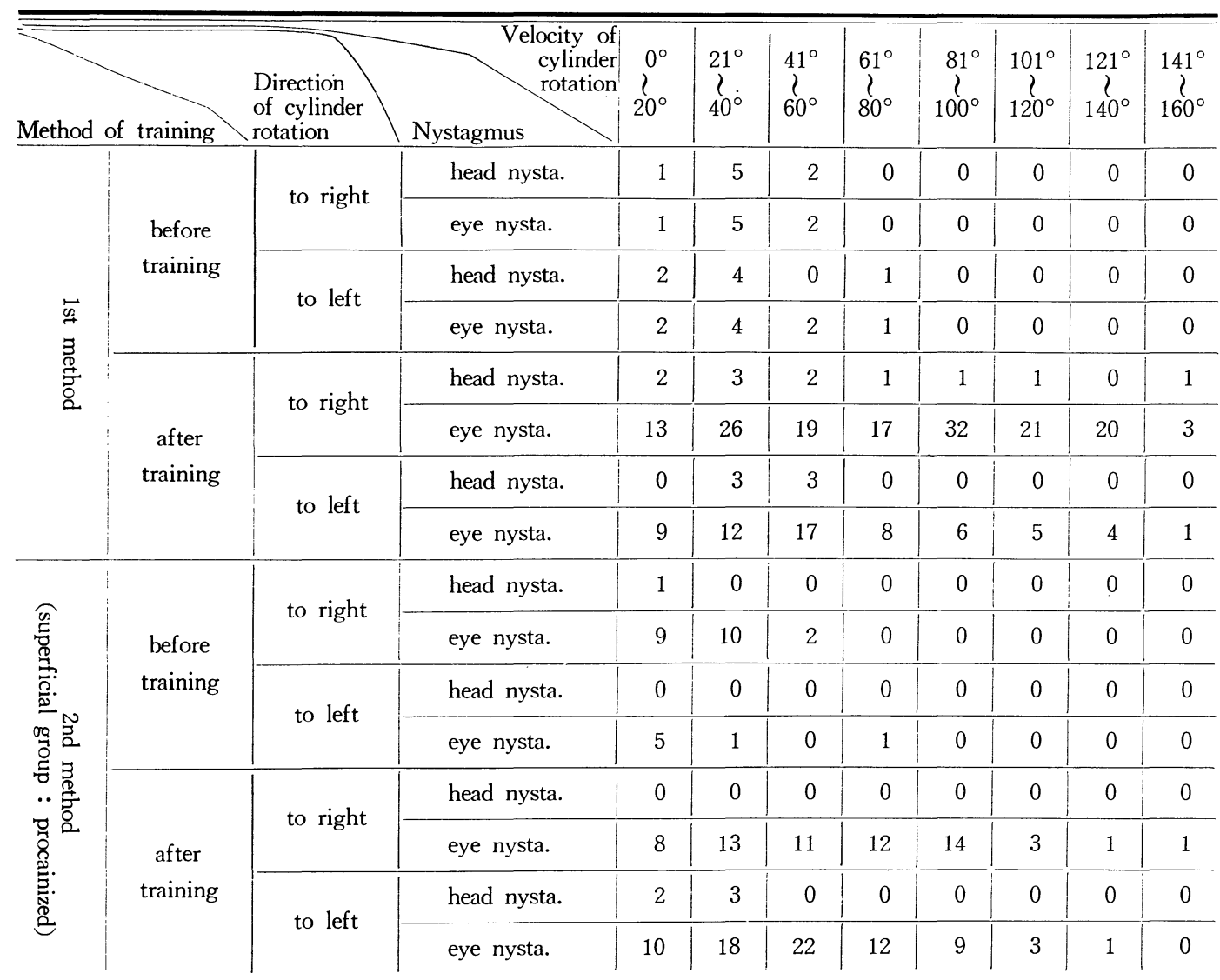

条件下の視運動刺激適応性向上の状況が，同一ウサギについては後述する).

において比較検討されなければならない。（この問題

\section{III 総 括と考案}

以上の実験成績より筆者は次ぎの 2 つの点について 申し述べたい. その第 1 は視性頭振と, 視性眼振の相
関についてである．その第 2 は，頸部筋群にプロカイ ン注射を行なう場合，何故に視性訓練による視運動刺 
激適応性向上が起こりがたいか？特に，浅層項筋群 プロカイン注射時の訓練に比し, 深層項筋群プロカイ ン注射時のそれの場合, 視運動刺激適応性の向上が更 に不良であるかについて考察を進めたい。

1）視性頭振と視性眼振との関係について,

桧, 寺山は頭部運動をストレインゲージ計器で, 眼 球運動を眼振電計で同時記録し，視性訓練により，両 器官の反射がぞのように変化するかを追求して，次ぎ の事実を得ている， イ）視性訓練により，視性眼振の

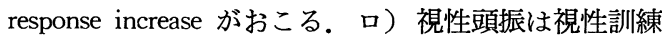
の一定時期に活潑に現れるが，更に訓練が進むと，そ の振巾と打数を減少する.しかしこのような動物に， 強力な視運動刺激を加えると，視性頭振が再び活潑に より出現しこれと共に視性眼振の振巾と打数が増大 する. (Hinoki and Terayama ${ }^{14)}$ )。この事実は，筆者 の実験においても再確認されている，桧，寺山らの行 なつた視性訓練実験では大円筒回転は各種の等速回転 が用いられ(例へば, 1 回転 $/ 40$ 秒, 1 回転 $/ 20$ 秒, 1 回 転 $/ 10$ 秒等), ある一定時間内（40秒間）の視性頭振と 視性眼振が同時に記録されている。そして筆者の行な つた実験では大円筒は角加速度 $1 \% / \mathrm{sec}^{2}$ で初速 $0{ }^{\circ}$ から 最高速 $160^{\circ} / \mathrm{sec}$ まで，加速回転されている，さて筆者 の実験では，視運動刺激の反覆をうけないウサギ，す なわち, 未訓練ウサギでは, 視性頭振, 視性眼振, と もに円筒回転低速度の部分でのみ出現し，円筒が中等 度以上に速くなるとその出現は不活潑となり，更に， 円筒回転が速くなると消失するものが多い。しかし， 視性訓練が進むと，丹筒回転が速くなつても視性眼振 が活潑に発来する様になる。このことは，桧，寺山の 実験で訓練後の動物では, その動物が訓練前, 反応し 得なかつた高速円筒回転にも，よく応答し得るように なる成績と一致する。

この場合興味あるのは，視性頭振の態度である．訓 練後の動物にあつては多くの例で，未訓練時，低速の 円筒回転に対して出現していた視性頭振が却つて不活 潑になり，円筒回転が比較的高速になつて，明瞭に出 現するようになることである。この事実は，桧，寺山 らの実験で未訓練動物では，低速の 円筒回転に 対し て，視性頭振をみるが，訓練のすすむに従つて，この 頭振が不活潑となる事実. およびより速い円筒回転を 課すると，再びこれに応じて，視性頭振が明瞭に出現 する事実とよく一致している，すなわち，筆者の実験 でも，また，「視性頭振は視器のみでは応じきれない 強烈な，視運動刺激に個体がさらされる場合．視性眼
振の発来を促進し，視器の視運動刺激適応性を助長す る点に，その平衡生理的役割を有する」という結論を 再確認し得た。 そして, この結論は, その程度の差こ そあれ，頸部が正常であつても，頸部にプロカイン注 射が行なわれている場合であつても原則的にあてはま ることは，上述した通りである.

2）頸筋にプロカイン注射を行なつた条件下で視性 訓練を行なつた場合は何故に，視運動刺激，適 応性向上が良好でないのか？

この問題を明らかにするために，以下のべる諸家の 報告は役立つと考えるので，それを先ず申し述べた い. Biemond, の研究によると頸部知覚神経中 $\mathrm{C}_{1} \sim \mathrm{C}_{4}$ までの線維は，下前庭神経核 (interior vestibular nucleus）と線維連絡を有するという(Biemond $\left.{ }^{2)}\right)$.このこ ことついては, Magnus, de Kleyn, 最近では Philipszoon もほほ同意見である (Magnus, de Kleyn26), Philips$\left.\mathrm{zoon}^{30)}\right)$. Kornhuter らの意見では. 視器, 迷路, 深部 受容器よりの求心性インパルス, 及び大脸皮質, 四丘 体（上丘）よりの随意性，不随意性のインパルスは， 脳幹網様体に於て積分され, 眼球運動核の activity control するという (Kornhuber25)). Pasik らは猿を用 いて，その脳幹に障害を与える際には，視性眼振の発 現が著しく不良となる事実を挙げ (Pasik $\left.{ }^{29)}\right)$, 桧, 黒沢 らはクロールプロマジンを投与して，正常人の脳幹の 機能を一過性に封鎖すると，視性眼振の発来が不活潑 となるばかりでなく，左眼および右眼の眼振の打ち方 が不均衡になる事実を挙ている(桧, 黒沢 $\left.{ }^{211}\right)$ 。これら の報告は, 視器の機能が脳幹の機能と密に結びついて いることを意味している。一方, Magnus 以来, 脳幹 (特に中脳)が迷路性立直り反射の中枢的位置を占めて いることは，よく知られている $\left(\mathrm{Magnus}^{27)}\right)$. そして 迷路性眼振に関しては，ウサギにクロールプロマジン を投与して，その回転後眼振が著しく低減する事実を 戸塚らが報告している (户塚, 鈴木(睦)，鈴木(淳), 徳 増 ${ }^{34)}$ )。このような事実は, 何れも脳幹（特に網様体） が視器, 迷路, 深部受容器(特に頸部)等の平衡器と密 なる連関を有する脸分野であることを示している．換 言すれば, 視器, 迷路, 深部受容器は, この脳分野を 中心に密接な機能的紐带を有しているともいえよう. 従つて, 頸部梁部受容器よりのインパルスを急激に低 下または，遮断する操作を行なう場合には，脳幹にお ける視器, 迷路, 深部受容器の機能的紐帯は破綻を来 し，ひいては眼球，軀幹，四肢に著明な平衡失調を来 すことは当然考えてよいことであろう，桧，黒沢は正 
常成人の深部項筋群 $\left(\mathrm{C}_{2}\right.$ の高さ) にプロカインを注射 した際に発現する眩暈，平衡失調を，このメカニズム を持つて考え (桧，黒沢21)，桧，寺山はモルモット を用いて，その深層項筋群にプロカイン注射を行なう と，著明な身体平衡失調を惹起し，視性反射が著しく 不良となる事実を見い出し，その成因をその操作によ り脳幹の機能が急激に破綻したためのものであろうと 考察している (Hinoki and Terayama ${ }^{15)}$ ).

更に，以上の事実に連関して，次の事実も重要であ る. Magoun らの研究によると，脳幹網様体賦活系に は各種の知覚神経よりのインパルスが側枝を介して流 入し，賦活系は一定の興奮準位を維持する仕組みにな つている。そして，この部は視床を介して，大脳皮質 の興奮性に重大な影響を与えるという $\left(\right.$ Magoun $\left.^{24)}\right)$. 一方，大脳皮質が条件反射の形成や学習効果の確立に 重要な役割を果すことはパブロフ以来，多くの研究が ある $\left(\right.$ パブロフ $\left.{ }^{31}\right)$ )。 また筆者の研究に連関していう と，福田，桧はモルモット，ウサギの大脳皮質や，ウ サギの Hyper-striatum（哺乳類大脳皮質に相当する機 能を有するといわれている）をあらかじめ破壊してお くと，視性訓練による視運動刺激適応性向上は著しく 不良となるという事実を上げている(福田，桧 $\left.{ }^{13)}\right)$. と ころで，上述したように大脳皮質の興奮性は，脳幹網 様体の機能の在り方によつて著しい影響をうける．従 つて，大脳皮質に直接的侵擎を加えなくとも，脳幹の 機能を低下させるような操作を行なう場合は，当然， 大脳皮質の興奮準位は低下し，皮質の機能は異常を来 すことになる，そして，このような条件下に条件反射 や学習の効果が確立されがたいことは，当然考えてよ いことであろう。

問題は筆者の行つた頸筋(特に深層項筋)へのプロカ イン注射が果して脸幹網様体(特に賦活系)の機能に一 定の影響を与え，ひいては大脳皮質の機能を低下せし めるかどうかである、この問題の最終的解決は，なお 多くの実証を必要とするが，次ぎの事実はこの問題の 解決に一つの手がかりを与えるものと思う。

桧，沢田，近藤らはウサギを用い，その大脳皮質 (visual cortex, sensory cortex, motor corter, limbic cortex）より脳波を誘導し，視運動刺激を加えた際，脳 波がどのように変化するかを探ると共に，視性眼振を 同時記録して，両者の関係を明らかにしようとしてい る. 彼等によると，第二頸椎推弓の高さで深層項筋群 にプロカイン注射を行なうと，皮質紡錘波とみなされ る脸波が，安静時にあつても，多発するようになる。
そしてこのようなウサギに音響刺激を与えた場合に は，正常ウサギに見られるような典型的な arousal patternが脳電図に出現しがたくなる，また，このよう なウサギに視運動刺激を加える場合，視性眼振の出現 は不活潑であり，視運動刺激中でも，脳電図上には， 皮質紡鍾波を考えられる脸波がしばしば現れ，頸部に 何等操作を加えないウサギに見るような脸波の arousal reaction がみとめられがたくなる，すなわち，深層項 筋群にプロカイン注射を行なうことは大脸皮質の興奮 準位を低下させるように作用することが脳電図よりう かがわれる(桧，沢田，近藤 $\left.{ }^{19}\right)$ ）音響刺激等の知覚刺 激により，脳波が arousal pattern を示すのはこれら の刺激により脳幹網様体賦活系が activate され，その 興奮が大脳皮質に投射されて大脳皮質興奮準位が上昇 するが故とされている(Magoun $\left.{ }^{25)}\right)$.

このような事実より案ずると頸部へのプロカイン注 射で大脳皮質が興奮準位が低下し，音響刺激や視運動 刺激で arousal reaction を示しがたくなるのはプロカ インの頸筋注射により脳幹網様体䟼活系の機能が低下 した故と理解してよいと思う。（勿論，直接脳幹部よ り，深部脳波を誘導していないのでその最終的結論は さしひかえたいが)

以上の事実より案じて筆者は「頸筋へのプロカイン の注射は, 視器, 迷路, 深部受容器の機能的紐帯を急 激に破綻させ，そのインパルスが統合させるべき脳幹 は混乱に陥いり，ひいては，大敛興奮準位を低下させ る.この条件下にあつては，たとえ視器より正常なる インパルスが中枢側におくられたとしても，これをう けとめて高次の視性平衡反射を形成する機能は中枢側 には期待し得ない.これが頸部にプロカイン注射を行 なつた場合，視性訓練による視運動刺激適応性向上を 著明に妨げる理由となつたもの」と理解している。

それでは深層項筋群の深部受容と浅層項筋群のそれ は視性訓練において，どちらがより有効に，視器に協 力して視運動刺激適䧹性獲得にあずかるものであろう 加?

先きに述べた成績より考えると，浅層項筋群プロカ イン注射時の訓練の場合に比し，深層項筋群プロカイ ン注射時のそれでは良好な視運動刺激適応性向上が得 られがたい印象をうける。しかしここで注意しなけ ればならない事は同一動物において，この二者を比較 しなければならないことである、訓練や学習の実験に おいては，被検動物の素質が非常に大きな役割を果す ことがあるからである，従つて同一動物を用い，次ぎ 
の3つの条件下に実験を行ない，各々の成績を比較し てみた，その代表例について，視性訓練による視性眼 振の変動を示したのが図(14)である. 図は，ウサギNNo. 1 を使用し 円筒右まわしによる視性眼振の変動が 示し てある。四示したように視性訓練により視性眼振の response increase は何れの条件下でも成立している. しかし，その程度には差がある，すなわち，頸筋が正 常の場合の訓練では最も明瞭に，視性眼振の response increase がおこり，深層項筋群にプロカイン注射をし たそれではこの現象の成立が最も不良である。この事 実は頸筋の中でも深層項筋群の媣部受容器が，視性訓 練効果獲得に最も重要な役割を果すことを意味してい る.

それでは何故にこのような成績を得られたものであ ろうか?

すでにのべたように $\gamma$ 線維は骨格筋の tonus に重要 な影響を有している.そして Magnusのいう Haltungsreflex の発現に欠くべからざる役割を果している，従 つて，姿勢構成や平衡維持に重要な役割を果す骨格筋 ほど，この神経線維の機能に依存するところが多い.

処で，上述したように Matthewsによると， $\gamma$ 線維 はプロカインに対して抵抗力が弱いので，同量のプロ カインを与えられた場合，この神経に依存する率の高 い骨格筋ほど，その機能失調が大である筈である。

さて，ここで問題にしている浅層項筋群，深層項筋 群が姿勢構成や身体平衡維持において果す役割を考え
てみたい. 内海の研究によると深層項筋群は赤筋の特 徵を有し, 浅層項筋群は白筋の特徴を有している（内 海 $\left.{ }^{38)}\right)$. そして，赤筋が姿勢構成に関係する骨格筋で あることはよく知られているところである．従つて， 深層項筋群は浅層項筋群に比して $\gamma$ 線維の分布がより 大で，その影響を受け易いことは当然考えてもよいで あろう。 $\gamma$ 線維がプロカインの影響をうけ易いこと は，上述したようにMatthews がすでに実証している。 従つて，プロカインを注射した場合，この神経に依存 する率の高い深層項筋群の機能失調は浅層項筋群に比 し，はるかに大であることも当然の帰結であろう。

さて，Campbell らによると，ここでのべている深 層項筋群は眼前を移動する事物を, 視器が注視し, 随 従する際重要な役割を果すという (Campbell and Parsons $\left.^{4)}\right)$. Campbell らによると，脳幹網様体，および medial longitudinal fasciculi は, この項筋群の機能深 く連関し, 上述の諸器官の協応運動にも重要な関係を もつという. 従つて，今，深層項筋群にプロカイン注 射を行ない，その部に存する深部受容器の機能を急激 に遮断する際には，脳幹を中心とする中枢神経系の機 能は重篤な破綻を来す筈である，中でも第二頸椎椎弓 の高さの筋群，すなわち， M. rectus capitis dorsalismajor et. minor, M. obliques capitis inferior, M. transverso-occipitalis 等の深部受容器の機能の低下は, 中枢 側の 機能の 破綻に重要な関係をもつものと考えられ る，因みに，桧，沢田，近藤の成績より案ずるに浅層

Charge in optic eye nystogmur ir.duced by optic training .

Troining was made on the same rabbit under the following three different conditions.

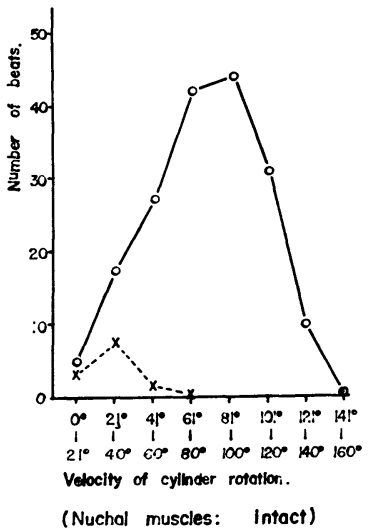

(Nuchal muscles: Intact)

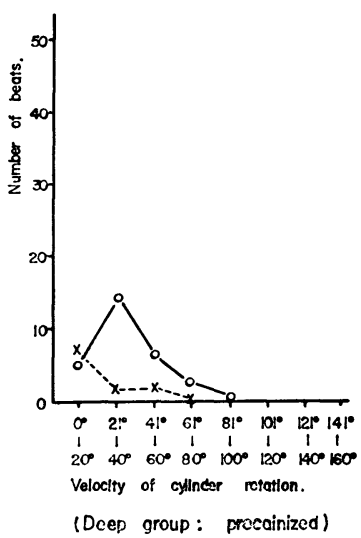

Fig. 14

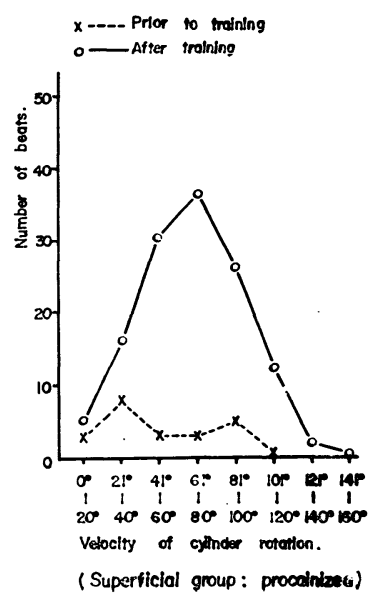

(Superficial group: procoiniase) 
項筋群（第三頸椎の高さ）へのプロカイン注射では， 皮質脳波の 变化は明瞭でない(桧, 沢田, 近藤21)

\section{VI 結}

このことも，上述した筆者の考案を更に裏付けている ものと思う。

1）動物に一定量の視運動刺激を考えると，視性眼振は response increase 現象を来し，視運動刺 激反覆負荷前, すなわち, 視性訓練前には反応し得なかつた高速の円筒回転に応答して活潑な視性 眼振を発来するようになる。視性頭振は視性訓練が進むにつれて低速の円筒回転（従つて，その視 運動刺激は被検動物には適刺激と考えられる）には却つて出現し難くなり, 円筒回転がより高速に なると活潑に出現する傾向を示す。

2） 頸部項筋（第二～第三頸椎の高さ）にプロカインを注射し，その筋に分布する $\gamma$ 線維の機能 を一過性に低下，又は脱落させ，ひいてはその部の深部受容器の機能を低下または脱落した状況に おき，視性訓練を行う場合には正常ウサギにみられるような明白な視性訓練効果がおこりがたくな る。特に, この傾向は深部項筋 $\left(\mathrm{C}_{2}\right.$ の高さ) にプロカインを注射した条件下の視性訓練において著 しい.

3）深層項筋群へプロカインを注射し，視性訓練を行つた際，視性訓練効果が良好に得られない 理由を桧, 沢田, 近藤らの行つた実験成績を基として推察した。すなわち，乙の部の筋群にプロカ インを注射すると，乙の筇群の深部受容器よりの求心性インパルスは急激に低下し，脳幹網様体の 機能を低下させ，ひいては大脳皮質興奮準位を下げる，かかる条件下では視性訓練してす良好な視 運動刺激適応性向上は望み得ないと推論した。

稿を終るに臨み, 終始御慇篤に御指導と御校閲を賜りました恩師, 桧 学教授に心から深謝すると共に, 本 研究に際し，種々御助言戴きました北原正章元助教授，寺山邦昭講師，また実験に御協力下さつた教室員各位に 深く御礼申し上げます。

なお，本論交の要旨は第 8 回国際耳鼻咽喉科学総会，第48回岩手地方会例会において報告した.

\section{主 要 文 献}

1) Aschan, G. : Response to rotatory stimuli in fighter piolts, Acta Otolaryng: (Stckholm), Suppl. 116, 24, 1954.

2) Biemond, A. : Further observations about the cervical form position nystagmus and its anatomical base, Proc. Nederl., Akad., wet., 43, Cit. from Bos, J. H. : On vestibular nystagmus without causative endolymph displacement, p. 21, Amsterdam, 1962.

3) Bos, J. H. : On vestibular nystagmus without causative endolymph displacement, p. 21, Amsterdam, 1962.

4) Campbell, D. G., and Parsons, C. M. : Reffered head pain and ts concomitants, J. nerv. ment. dis., 99, 544-551, 1944.

5) Crampton, G. H. : Habituation of ocular nystagmus of vestibular origin, p. 332-344, Har- per and Row publishers, New York, 1961.

6) Dodge, R. : Habituation to rotation, J., exp. physiol., 6, 1, 1923.

7) Fukuda, T., Hinoki, M., and Tokita, T. : Static and kinetic labyrinthine reflex, Acta Otolaryng. (Stockholm), 49, 468〜477, 1958.

8) Fukuda, T., Hinoki, M., and Tokita, T. : Provocation of labyrinthine reflex by visual stimuli, Acta Otolaryng. (Stckholm), 48, 425 〜32, 1957.

9）福田 精：運動と平衡の反射生理. p. 177-185. 医学書院, 東京, 1957.

10) 福田 精: 同上, p. 96 ,

11）福田 精: 同上, p. 92 94,

12）福田 精: 同上, p. 92 96,

13）福田 精: 同上, p. 104 110,

14) Hinoki, M., and Terayama, K. : Studies on 
optic head nnystagmus from the stand-point of body equilibrium, Acta Otolaryng. (Stockholm), in press.

15) Hinoki, M., and Terayama, K. : Physiological role of neck muscles in the occurrence of optic eye nystagmus, Acta Otolaryng. (Stockholm), in press.

16) Hinokl, M., and Kitahara, M. : An application of strain-gage-type instruments to the analysis of the equilibrium function in human subjects and animals, Acta Otolaryng. (Stockholm), Suppl. 179, 114 115, 1963.

17）桧 学, 沢田克郎, 近藤正彦, 金谷春之：視 刺激適応性獲得過程の脳波学的検討 ; 第 1 報, ウサギ頭皮上脳波による観察，13回日本脸波学 会 1963 .

18）桧 学, 沢田克郎, 近藤正彦, 金谷春之 : 視 刺激適応性獲得過程の脳波学的検討; 第 2 報, 片側遮眼ウサギの頭皮上脳波と視性眼振の変化 を指標とする観察，第14回日本脳波学会 1964.

19）桧学, 沢田克郎, 近藤正彦: 頸性眩暈の発 現㙨転に関する実験的研究; 頸筋プロカイン注 射のウサギ皮質脳波におよほす影響（未発表）

20）桧学：耳科の立場よりみた頭部外傷後遺 症, 精神神経学雑誌, 67, 334〜335, 1965,

21）桧 学, 黒沢 吏: 頸筋項筋より誘発される 眩暈, 耳鼻臨床 $57,10 \sim 20,1964$.

22）北原正章, 佐藤利子 : 視機刺激介在下の人の迷 路反射, 耳鼻臨床 $56,576,1963$.

23) Kornhuber, H. H. : Periodische alternierende Nystagmus (Nystagmus alternans) und die Enthemmung des vestibulären System, Arch. Ohren-u.s.w. Heilk., 174, 196 197, 1959.

24) Magoun, H. W. : The waking brain (時実訳 : 脳のはたらき，p. 78〜 95, 朝倉書店, 東京, 1958),

25) Magoun, H. W. : The waking brain (時実訳 : 脳のはたらき，p. 83〜 85, 朝倉書店, 東京, 1958),

26) Magnus, R. : Körperstellung, p. 174, Julius
Springer, Berlin, 1924.

27) Magnus, R. : Körperstellung, Cit. from Fulton, J. : Physiology of the nervous system (坂本, 沖中, 時実訳 : 神経系の生理学, p. 180〜183, 1954),

28) Matthews, P. B. C., and Rushworth, G.: The relative sensitivity of muscle nerve fibers to procaine, J. Physiol., 135, 236, 1957.

29) Pasik, J., and Pasik, P. : Observation on the mechanism for optokinetic nystagmus, p. 111 116, Proceedings of International vestibular symposium on "Vestibular and oculomotor problems”, Tokyo, 1965.

30) Philipszoon, A. J. : Compensatory eye movements and nystagmus by stimulation of the vestibular organ and cervical nerve roots, Pract. Oto-Rhino-Laryng., 24, 198, 1962.

31）パブロフ：条件反射学（林嗃訳） p. 441〜 516, 三省堂 東京, 1937.

32) 鳥津 浩 : $\gamma$ 系の生理, 神経研究の最近の進歩, 3, 816, 1959.

33）時田 喬 : 視器, 迷路, 自己受容器 ; 意志運動 の協働よりみたニスタグムスの生理,耳鼻臨床, 54, 613, 1961.

34）戸塚之吉，鈴木睦郎，鈴木淳一，徳増厚二 : 迷 路性眼球振盪に対するクロールプロマジン系薬 剤の影響, 日耳鼻，62,256〜257, 1958.

35）寺山邦昭 : 視器, 迷路と頸筋, 項筋の自己受容 器, 日耳鼻 67, 1083 1084, 1964.

36) 寺山邦昭 : 日耳鼻, 1069 1070.

37）寺山邦昭：日耳鼻, 1083〜1085.

38）内海貞夫：前庭性筋反応について，第61回日耳 鼻総会シンポジム “前庭反応とその検查法” 別冊, 47, 1960.

39）楖原亮一：年令と視性眼振，耳鼻臨床，44，456, 1951.

40) Walshe, F. M. R. : Observations of the nature of the muscular rigidity of paralysis agitans and its relationship to tremor, Brain, 47, 159 $\sim 177,1924$. 